УДК 27-245=163.41"14"

$091=163.41 " 14 "$

$821.163 .41-97(082.2)$

821.163.41.09"14

https://doi.org/10.18485/godisnjak.2021.16.4

Томислав Ж. Јовановић*

Универзитет у Београду

Филолошки факултет
Оригинални научни рад

Примљено: 18. 09. 2021.

Прихваћено: 05. 11. 2021.

\title{
ПРЕПИРАЬЕ ЂАВОЛА СА ИСУСОМ ХРИСТОМ У СРПСКОМ ПРЕПИСУ С КРАЈА ХV ВЕКА
}

Овај апокриф са дуалистичким основама прожет је дијалозима између ђавола и Исуса Христа. Њихово препирање тече градационо и креће се кроз непрестано надмудривање. Притом су Христови ставови надјачали све ђаволове зачкољице којима је покушавао не само да га победи него и да му нанесе свеколико зло. Апокриф је познат у грчким и словенским преписима. Најстарији сачуван српски препис потиче с краја XV века и налази се у манастиру Никољцу. Овај препис узет је за основу издања текста овог апокрифа уз поређење са још пет других преписа.

Кључне речи: апокриф, препирање, Исус Христос, ђаво.

Посебност овог новозаветног апокрифа састоји се у непосредном надметању ђавола са Исусом Христом. Према току одвијања радње он

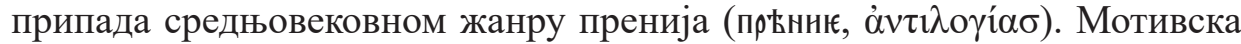
основа апокрифа лежи у делу Јевађеља по Матеју $(4,1-11)$ и Јеванђеља по Луки (4, 1-13), с тим што је библијски сиже сведенији. Апокриф је познат у грчким и словенским преписима са одређеним варијантама. На почетку апокрифа налази се опште место са Исусовим доласком на Маслинову Гору како би окупио апостоле и позвао их на четрдесетодневно

*tomjovan1@gmail.com 
пошћење. Разлог његовог доласка покренут је проразумевањем да ђаво спрема своју војску и да се због тога треба припремити за препирање са њим. Док су у једној грчкој варијанти наведена имена апостола Петра, Павла и Андреја (Vassiliev 1893: 4), које је Исус позвао на окупљање, њихова имена у словенским преписима (Otero 1981: 157-160) не појављују се. У апокрифу се препознаје идеја о два царства - земаљском и небеском, која се предочава у ђаволовом обраћању Исусу: „Ако си ти син Божији, онда иди на небеса и седи на престолу свом, јер су твоја небеса, а моја је земља!"” Ова идеја присутна је и у неким другим апокрифима и постала је наводно основа учења богумила. ${ }^{2}$

Ток препирања, односно надметања, између ђавола и Исуса одвија се устаљеним моделом. Ђаво изазива Исуса постављајући му најпре питања која више личе на одмеравање снага, а затим му задаје претешке задатке. Потом у дијалошком облику следи Исусов одговор којим се оповргава ђаво са свом својом злобом. На питање ђавола Исусу „Шта су дела моја?" у Исусовом одговору дочаравају се основне одлике зла које прате ђаволово портретисање: „Твоја дела су разбојништва, лоповлуци, блуди, зависти, жалост, огањ, тама, земљотрес, распре земаљске, ратови, свађе, братска завист." У сваком ђаволовом изазову леже мржња, завист, претња и спремност да се обрачуна са Исусом. Упутства ђавола о устројству са својом војском своде се на то да их он позива да стану сви испред њега, а он ће за њима и да тако пођу у бој са Исусом и његовим анђелима, у чему се у суштини предочава његов кукавичлук и страх од Исуса. Опис битке обележен је извесном сликовитошћу са наглашеном психолошком драматичношћу. Тако се од жестине надирања ђаволове војске „горе тресу и море мути", што улива страх међу анђелима. Од њиховог силног вапаја „Петар побеже од Господа три попришта”. Чак и када се вратио после Господњег храбрења, Петар је стао иза Исуса „гледајући преко рамена његовог". Петрово бежање подсећа на његово троструко одрицање од Христа, посведочено у јеванђељима (Мт 26, 69-75; Лк 22, 56-62).

У апокрифу се сукоб између ђавола и Исуса одиграва кроз исконско поимање борбе између добра и зла. Уз сву претећу силину ђавола и његове војске, обрт се догодио у тренутку када је Исус заповедио да сиђе облак са небеса који „узе ђавола и обеси га стрмоглавце за пете за облаке $97-106$.

${ }^{1}$ Сви наводи из апокрифа на савременом српском језику преузети из: Јовановић 2005 :

${ }^{2}$ Види: Jagić 1873: 79-95; Радченко 1910: 73-171; Иванов 1925, 19702 ; Драгојловић 1974; Драгојловић 1982; Ivanov 1976; Turdeanu 1950: 22-52; Turdeanu 1981: 176-218; Петканова 1982: 143-153; Yordanov [1994]: 143-153; Жаворонков, Турилов 2009: 471-473. 
небеске". Према устаљеном понашању у многим биткама, када војсковођа буде ухваћен и побеђен, његова војска то доживљава као пораз и зна се ко је победник, тако су се и ђаволове војске када им је вођа посрамљен разбежале „као дим” уз вапај: „Шта учинисмо, небози? Бежимо у дубине морске и у пећине јер кнеза нашег обеси Христос на облацима небеским!" Пошто је ђаво на тај начин претрпео пораз, он је молио Исуса да га ослободи обећавајући да ће чинити пакости онима који су до тада били на његовој страни: „Опрости ми, Господе, не погуби ме него ме пусти на земљу, да онима који вероваху у моје срамотно име чиним пакости, како би се сви обратили теби!” Милостивост, као једна од основних Исусових особина, показала се и овом приликом те је ослободио ђавола. С друге стране, доследност у ђаволовом лику оличена је у његовој незахвалности и подгревању новог непријатељства према Исусу. Жанровска оправданост непрестаног трајања пренија одвија се изнова, али више кроз ђаволове претње, најпре да се одмеравају пљувањем и снагом пљувачке, што Исус одбија оправдавајући то тиме што је његова пљувачка света као што је и његов дух. Мотив пљувања Христа, али у другом контексту, има одговарајуће место у Јеванђељу по Матеју, на коме се говори о ругању окупљених људи који су Христа кажњавали пљувањем и ударањем у лице (Мт 26, 67).

Такође још једно место из апокрифа има своју библијску паралелу, која није сасвим подударна, али је довољно препознатљива. Када је ђаво запретио да би, уколико је знао где се Исус родио, дошао тамо и убио његову мајку и њега, Исус је одговорио на језгровит и метафоричан начин да је то немогуће: „Ко може пшеницу жњети на чичку или вино са трња добити?” Сличан облик мудрог Исусовог казивања налази се у 16. стиху седме главе Јеванђеља по Матеју: „Еда ли се бере с трња грожђе, или с чичка смокве?” Одређени библијски одјеци попут наведених у овом апокрифу, као и у већини других ванканонских састава ове врсте, указују на неодвојиву тематску повезаност са кључним догађајима којима се изнова окретало у књижевним делима уз нове садржаје, најчешће прожете додатном фантастиком.

Даљи ток Препирања поприма епске размере начином на који Исус припрема кажњавање ђавола за његово коначно уништење. Изненађење које је Исус приредио ђаволу само по себи изазива ужас. Исус је заповедио да земља зине триста сежања у ширину од чега се тло затресло на све четири стране. Степен изненађења подигнут је на виши ниво тиме што је провалија настала невидљиво иза ђаволових леђа и што је Исус указао на њу као наговештај разрешења препирања са супарником: „Погледај, ђаволе, шта је иза тебе!” Пошто је ђаво желео да сазна шта је то и чему 
служи, Исус му је предочио да ће у тој провалији боравити свезан до скончања века. Сама дубина је немерљива и исказана на сликовит начин: „Ако тридесетогодишњи младић узме камен према својој снази и баци га доле у дубину, он ће пасти тек после трећег дана.” На питање ђавола шта ће после бити Исус му наговештава попут тумачења сна Јосифа Прекрасног Фараону да ће учинити да настане најпре добар а онда лош период за људски род: „Прве године родиће много жита и вина, а друге године учинићу да по читавој земљи не нађеш нити мерицу пшенице нити кабла вина." Следећи корак који ће Исус учинити јесте да ће убрзати време тако што ће „три године бити као три месеца, а три месеца као три недеље, а три недеље као три дана, а три дана као три часа, а три часа као три тренутка." Завршни чин даљег одвијања будућности према Исусовом предвиђању води ка доласку Судњег дана, што се на посебан начин дотиче завршне књиге Новог завета - Откровења Јовановог. Тиме је у овом апокрифном препирању Исус исказао своју победу над ђаволом: „Савићу небеса као свитак и зажећи ћу земљу као камин. И заповедићу мору и усахнуће као камен. И доћи ћу на место мојег судишта, које се назива Хузија. И ту ће доћи мајка моја која ме роди, и Јован Богослов, и Илија и Енох, који не искусише смрт. И тада ћу погубити тебе, ђаволе."

Најстарији сачувани српски препис Препирања ђавола са Исусом Христом настао је у периоду између $1485 / 95$. године и данас се налази у рукописној збирци манастира Никољца број 52, на страницама 66а-71a (даље скраћеница Ни). Поред њега, зна се за неке млађе преписе. Један од њих је у збирци Народне библиотеке у Београду, број 760, из прве деценије XVI века и на страницама 61a-68б (скраћеница Н). С краја XVI или почетка XVII века потиче препис без почетка који се налази у Богишићевом архиву у Цавтату, 2a (Мошин, број 15). Овај препис нисмо имали прилике да користимо. Из истог периода потиче препис из Архива ХАЗУ у Загребу, број III а 43, на страницама 186а-191б (скраћеница 3). У старој збирци Народне библиотеке у Београду, страдалој у немачком бомбардовању 6. априла 1941. године, налазио се препис из XVII века, број 273, на страницама 127б-143а. Апокриф је објавио Стојан Новаковић (скраћеница Но) (Novaković 1884: 86-89). Препис такође из XVII века постоји у Прагу, у

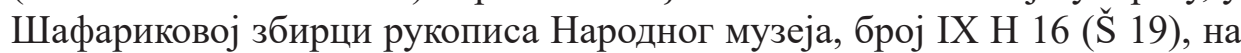
страницама 227a-231a (скраћеница П). Препис је објавио Јиржи Поливка (Polívka 1890: 200-203). Истом веку припада препис у зборнику Народне библиотеке у Софији, број 326, на страницама 41a-44a (скраћеница С).

Поређењем наведених преписа уочавају се извесне текстолошке разлике. Оне долазе пре свега као већ ранија раслојавања апокрифа према 
одређеној варијантности, али и као резултат већег уплива преписивача да понешто измене у затеченом предлошку. Понекад су разлике синонимске природе, али и промене које залазе у другачија значења. Као најстарији од наведених српских преписа узет је препис из збирке манастира Никољца број 52 за основу издања, које се налази у наставку овог прилога. Већ у наслову показују се одређена мимоилажења код преписа. Док је у Ни, Н, 3 и П жанровско одређење препреније, у С је препираније, а у Но нижу се чак три узастопна и повезана израза: сказаније, слово и препреније. Поред тога, ђаво се именује у наслову управо том речју у Но, Н, Но и П, док је у 3 сотона, а у С антихрист. Одступања међу преписима огледају се нарочито у две категорије речи - именицама и глаголима. Међу именицама наилазимо на шаренило какво показују следећа поређења:

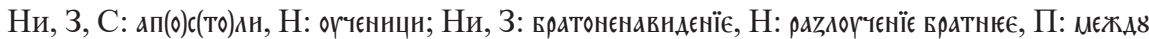
Братїєю лажн, ненавнсть, н всакаа неправаа, С: разляченїа вратїю; Ни, Н, З, Но, П: єзєро, С: ровь; Ни, 3: камнног, Н, Но, П: Фг'нь, С: пламен(ь); Ни, 3, Но, П: кнеъв, Н: канафнно, С: канафє; Ни, Н, Но, С: кьв'九ь, П, З: спваь; Ни, Н, 3, Но, П: мћра, С: вєдро; Ни, Н, 3, Но, С: шгнь, П: оганно варћнїє; Ни, Н, 3, С: пєтє, Но, П: нозъ; Ни, 3: плювотнна, Н, Но, П: слына, С: слнн'ка; Ни, 3: п’шеннце, Н, Но, П: жнта, С: тєннца; Ни, Н, 3, Но, С: раzвон, П: развоннычастьво; Ни, П: сважаєнїа, Н: каранїє, С: нєнавнс(ть); Ни, З, Но, П, С: сварн, Н: скврьнн; Ни, 3, Но, П: сов'ства, Н: г[о]споА [ь]ство; Ни, Н, 3, Но, С: сьвБтннци, П: светндннци; Ни, Н, Но, П, С: оүзамн, З: вєзамн; Ни, Н, З, П, С: храпанїа, Но: хранннь; Ни, Н, 3, П, С: часн, Но: чрьтнцє; Ни, Н, 3, П: чєА[ь]ца, Но: дъцца, С: чєднца; Ни, Н, 3, П, С: чрьте, Но: мьгновњнан ока.

\section{Глаголи у неким случајевима показују такође знатну разноликост:}

Ни, Н, 3, Но, П: алка, С: пос(ть) дрьжнт(ь); Ни, Н, 3, Но, П: алчємь, С: постнш сє; Ни, Н, 3, Но, П: вндьв'шє, С: вьzрьвшє; Ни, Н, Но, П: врьжеть, З: вьврьжеть, С: послеть; Ни, З, П, С: вьзнає, Н: двыжє сє, Но: вьздвнжє сє; Ни, З, С: вьсн, Н: рькль єсн, Но, П: рєчє; Ни, Н, 3, Но, С: знногтн, П: раступнтн сє; Ни, Н, 3, Но: наснщає, П: напнтаты, С: накрьмнт(ь); Ни, Н, 3, С: (бхл(н)чн сє, Но: шпльчн сє, П: овлєчє сє; Ни, Н, 3, П, С: раздроүшнтн; Ни, Но, С: поєтн сє, Н: похрапатн, П: хнтнтн сє; Ни, З, Но, П: пондБтє, Н: ндете, С: прБндете; Ни, Н, З: поплюють, Но: терають, П: вьсплують, С: ФПлюты; Ни, Н, З, П: прїндє, Но: вьшьдь, С: прнблнжншуМ сє; Ни, З, П: прнш'Аь, Н, С: ншль, Но: шьдь; Ни, 3: прогнћва сє, Н, Но, П, С: разгнъва сє; Ни, Н, 3, Но, П: прьпрнц' сє, С: оүаолєть; Ни, Н, 3, П, С: расконвнль, Но: раскопаль; Ни, С: рек'ль, Н, П: свднль, Но, З: расванль; Ни, Н, З, Но, С: рєчє, П: гаагола; Ни, Н, 3, П, С: скон“ча сє, Но: сьврьшн сє; Ни, 3, Но: сьБраш (є) сє, Н, П: сьвькоүпнш(є) сє, С: вь сьвькоүпндь; Ни, 3, Но, П: сьтворнть, Н: творнть, С: сккончаєт(ь);

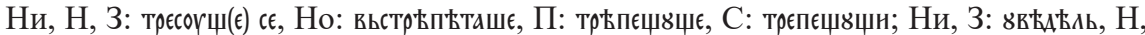
П: вндьль, Но: зналь, С: знаюаль.

Одступања међу преписима уочавају се у обиму појединих целина које у неким преписима постоје, а у другим их нема. У односу на Ни среће се изостављање целина у следећим преписима: 
$\mathrm{H}$ :

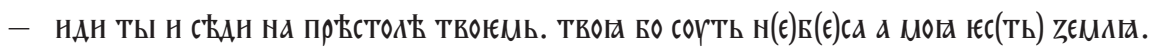
аџє $\Lambda$ Т то.

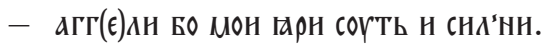

H, П:

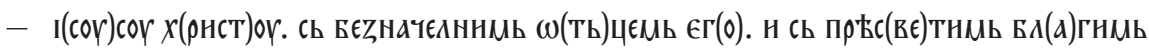
н жнвотворєџни' тн А(ог)хомь.

Ho:

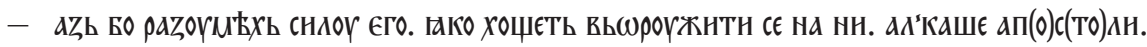

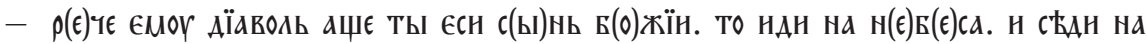

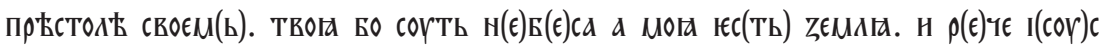

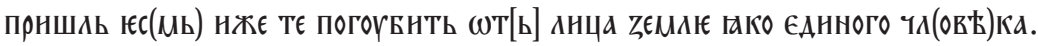

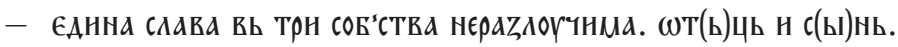

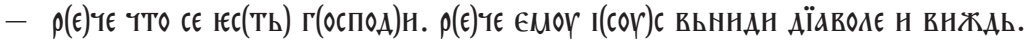

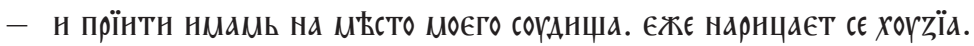

C:

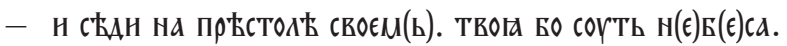

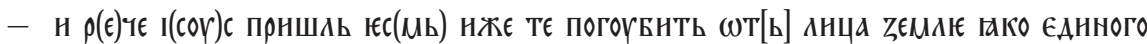

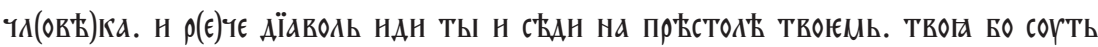

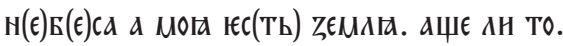

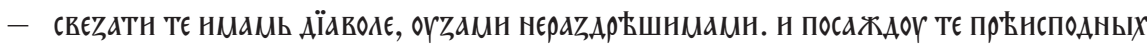

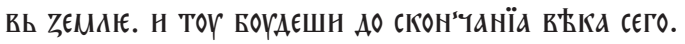

Обрнута појава везана је за проширења у односу на Ни:

H, 3:

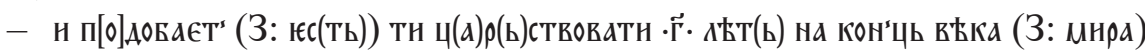
сєГО.

3:

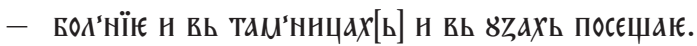

Ho:

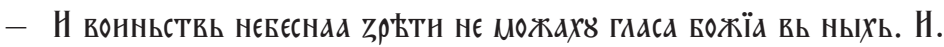

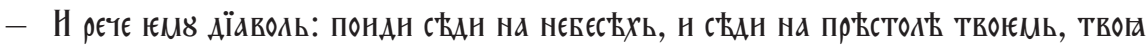

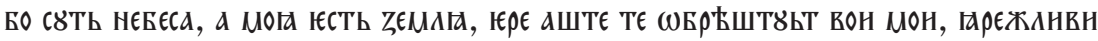

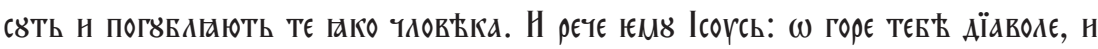

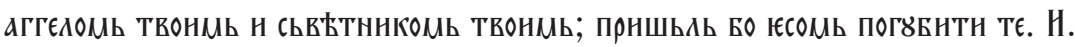


$\Pi:$

- СЬ МНОЮ АОБРОДЬ(Т)ЕЛїЮ Н ПРЬЖАЬ ВЬСЕХ WТСЕЧЕТ СЕ АЕАЬ ТВОНХ.

C:

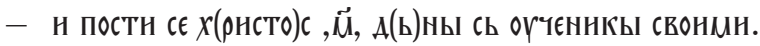

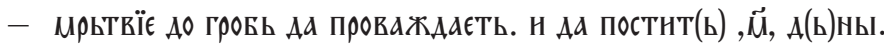

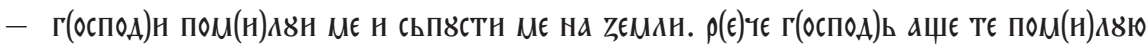

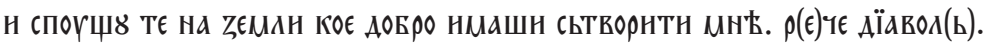

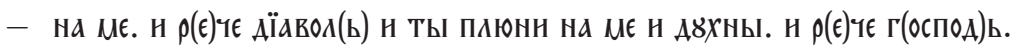

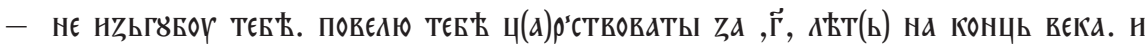

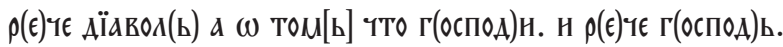

Осим наведених разлика, већа одступања постоје у другачије обликованим местима, која су понекад значењски блиска једна другима, али и уносе различита решења:

Ни : Но

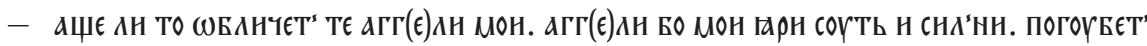

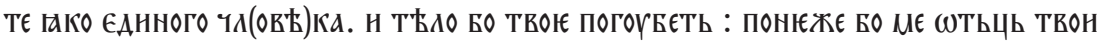
СЬВРЬЖЕ СЬ НЕБеСЬ НА ZеМАЮ.

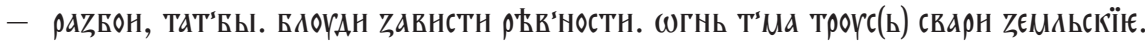

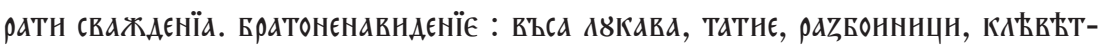

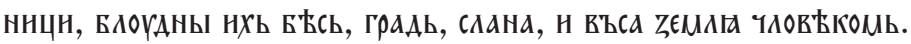

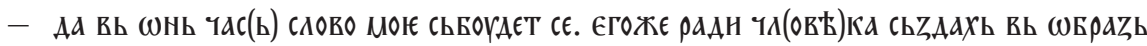
Мон н не Хоџоү

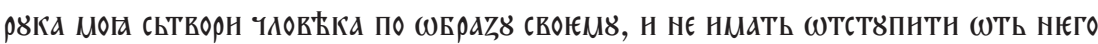
въ вЊккы ацннь. Н.

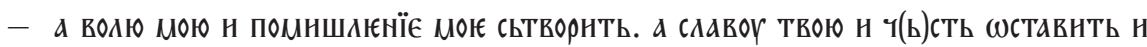

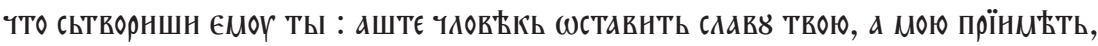
тто сьтворниь єе४. Н.

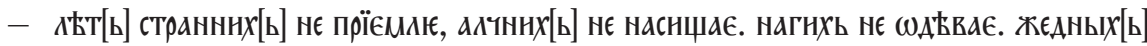

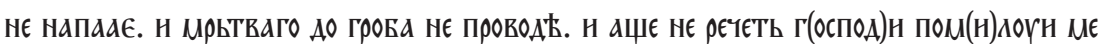

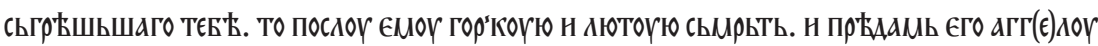

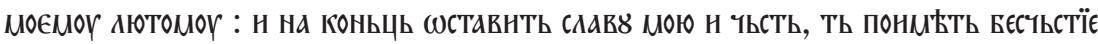

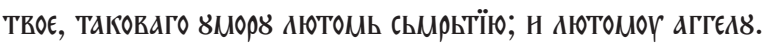

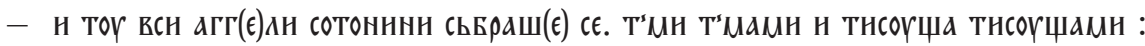
Н ТУ дїАБОЛЬ СьБра вс8 снА४ своЮ.

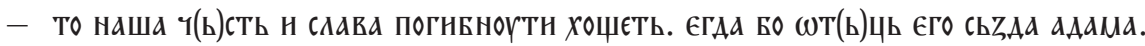

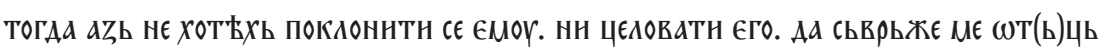

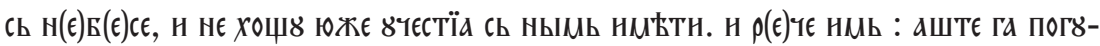
БнМо, наша слава н чьсть. 


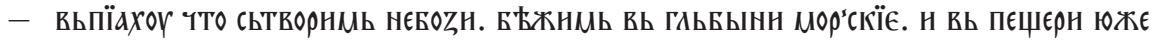

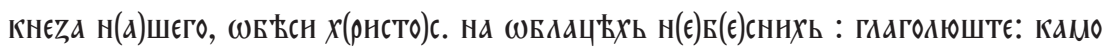

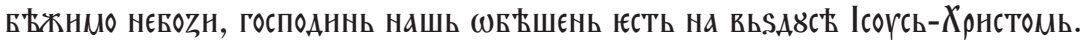

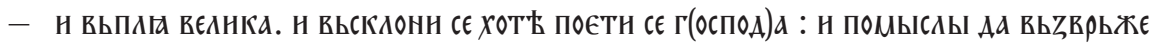
на Господа, н ПрІнде кь нієU४ Ісоүсь. н.

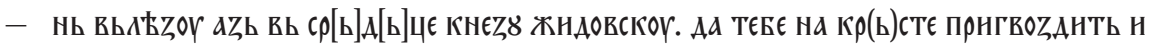

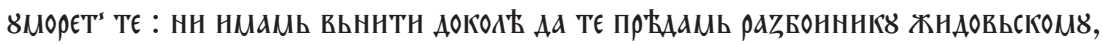

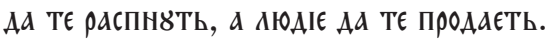

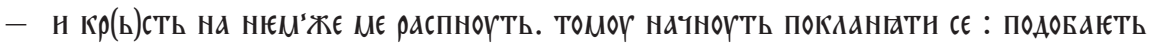

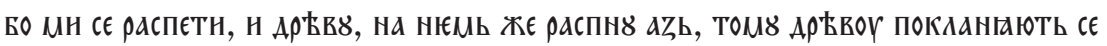
AHAIE.

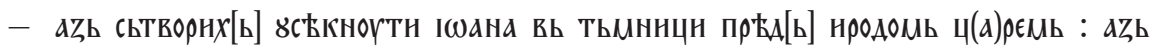
вьнндохь вь срьдЦе н Іродоү цару аа Іалн'на zаколють.

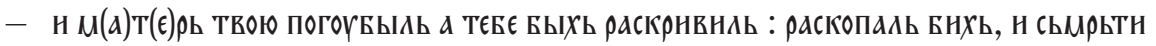
БнХь ПОложнль, н тєББ БнХь ПрЊААль.

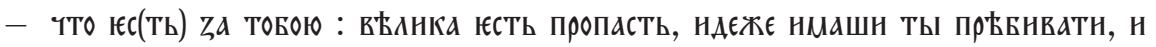
ПрНZНВаюШТН НМЕ ТвоЮ.

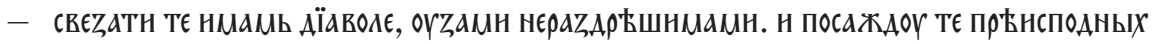

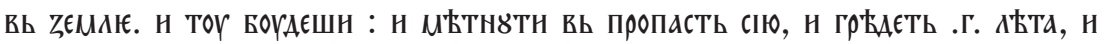
Нє МОжЕТЬ АОНТН АО АНА, ТОАНКА ІеСТ ПрОПаСТЬ СІа, ГАє НМаШН ТЫ ПрББНБАТН

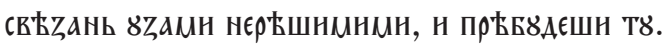

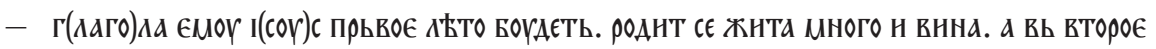

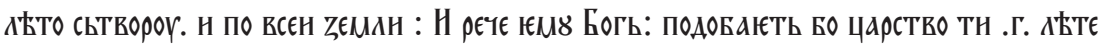

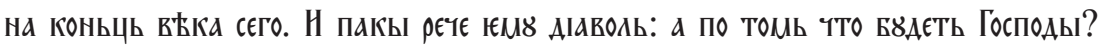

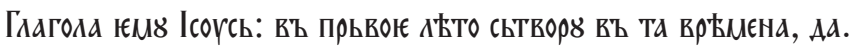

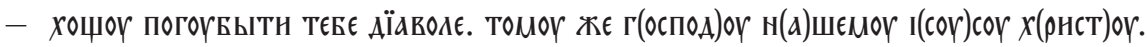

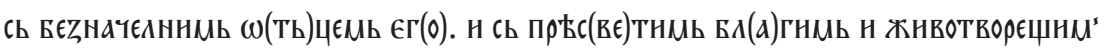

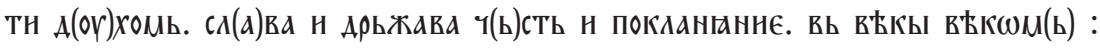

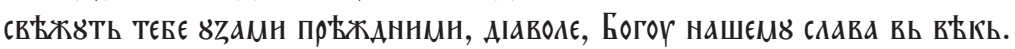

Ни : П:

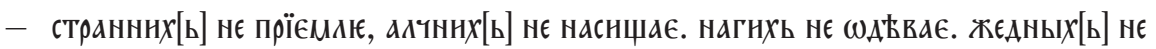
нападе. н Мрьтваго до гроБа не проводБ. н ащє не : вь АєАБХЬ ТвонХЬ н ка Мнє

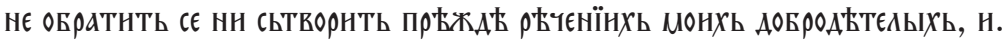

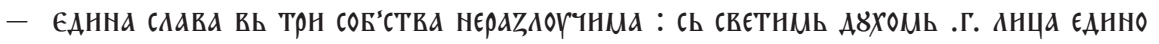
БОЖьСТЕО Н єАННА сААБА вЬ .Г. СОБЬСТЬБА НЕРАZАУЧНМАА. 
Ни : Но : П:

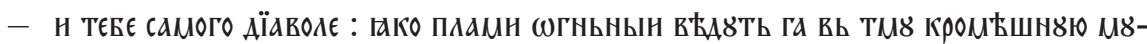

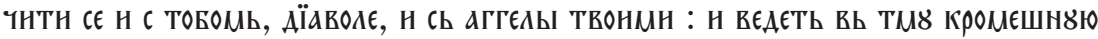

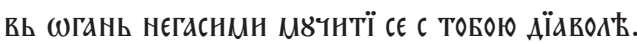

Ни : Но : С:

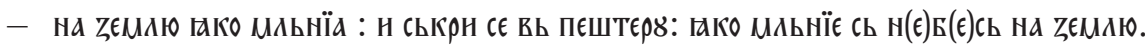

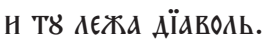

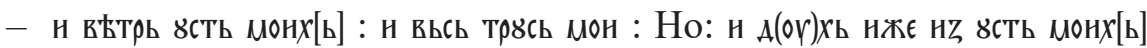
HCXOАHT(ь).

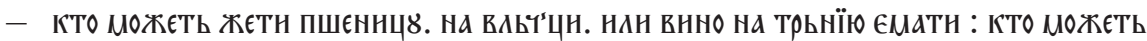

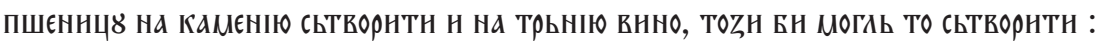

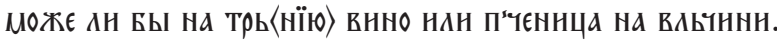

Ни : С :

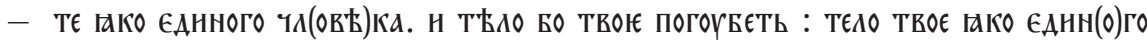
чА(ОВБ)К КА.

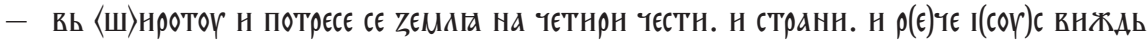

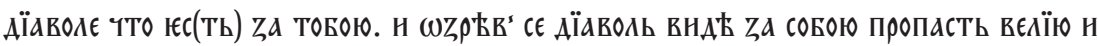

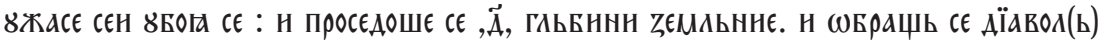
Н вНАЕ н $\rho(\epsilon)$ чЕ чТО ЕС(ТЬ) СЕ Г(ОСПОА)Н.

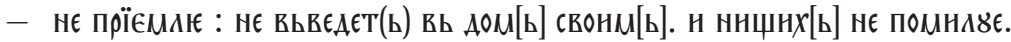

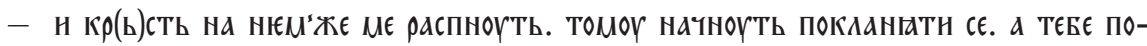

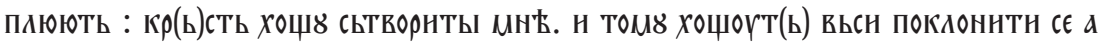
тєББ (ППАЮТЫ дїАБОАє.

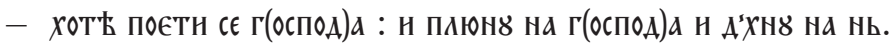

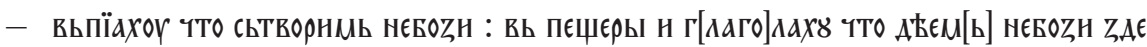
стоющн. нь.

Овако разграната варијантност међу српским преписима упућује на знатна мимоилажења. Она уносе пре свега разноликост израза, синтаксичка преобликовања и лексичка обогаћења. Путеви којима су текли правци неуједначености данас су неухватљиви, али они потичу још из грчких варијанти, које су се у словенским преводима још више раслојавале до нових типова и група датог апокрифа. Оваква појава није посебност само овог састава, већ је присутна и код већине других дела ове врсте, што указује на слободније држање појединих преписивача приликом стварања нових преписа. На основу изнетих запажања показује се да су најблискији преписи Ни и 3. Делимично би могли да се сврстају у једну групу Н, П и $\mathrm{C}$, док се препис Но највише удаљава од свих осталих. 
У додатку прилаже се приређено издање апокрифа Препирање Ђавола са Исусом Христом на основу преписа Ни уз текстолошко праћење преписа Н, 3, Но, П и С.

\section{ЛИТЕРАТУРА}

Драгојловић 1974: Д. Драгојловић, Богомилство на Балкану и у Малој Азији, Београд.

Драгојловић 1982: Д. Драгојловић, Богомилство на православном Истоку, Београд.

Жаворонков, Турилов 2009: П. И. Жаворонков, А. А. Турилов, Богомильство, Православная энциклопедия, 5, Москва, стр. 471-473.

Иванов 1925: Й. Иванов, Богомилски книги илегенди, БАН, София [1970²].

Јовановић 2005: Апокрифи. Новозаветни. Приредио и на савремени језик пренео Томислав Јовановић, Библиотека Стара српска књижевност у 24 књиге, књига 23, II том, Просвета - Српска књижевна задруга, Београд, стр. 97-106.

Петканова 1982: Д. Петканова, Богомилството и апокрифната литература, Старобългаристика, VI, 3, София, стр. 143-153.

Радченко 1910: К. Ф. Радченко, Этюды по богумильству. Народные космогонические легенды славян в их отношении к богомильству. Известия ОРЯС, 4, Санкт-Петербург, стр. 73-171.

Ivanov 1976: J. Ivanov, Livres et Légendes bogomiles (Aux sources du catharisme), Paris.

Jagić 1873: V. Jagić, Apokrifi bogomila popa Jeremije, Novi prilozi za literaturu biblijskih apokrifa, Opisi i izvodi iz nekoliko južnoslovinskih rukopisa. Starine JAZU, V, Zagreb, стр. 79-95.

Novaković 1884: S. Novaković, Apokrif o prepiranju Isusa Hrista sa djavolom, Starine JAZU, XVI, Zagreb, стр. 86-89.

Otero 1981: A. de Santos Otero, Die handschriftliche Überlieferung der altslavischen Apokryphen, Band II, Der Akademien der Wissenschaften in der Bundesrepublik Deutschland. Patristischen Kommission, Berlin, стр. 157-160.

Polívka 1890: Gj. Polívka, Opisi i izvodi iz nekoliko jugoslavenskih rukopisa u Pragu, Starine JAZU, XXII, Zagreb, стр. 200-203. 
Turdeanu 1950: E. Turdeanu, Apocryphes bogomiles et apocryphes pseudo-bogomiles, Revue de l'histoire des religions, I, CXXXVIII, 1950, стр. 22-52; II, CXXXIX, стр. 176-218.

Turdeanu 1981: Apocryphes slaves et roumains de l'Ancien Testament, par Émile Turdeanu, Studia in Veteris Testamenti Pseudepigrapha, 5, E. J. Brill, Leiden 1981, стр. 1-74.

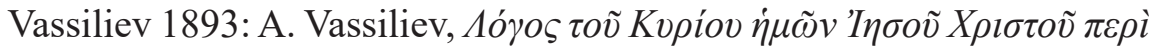

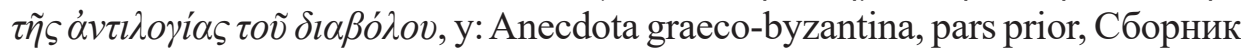
памятников византийской литературы, Mosque 1893.

Yordanov [1994]: S. Yordanov, Quelques remarques sur l'origine des idées dualistiques dans un monument de la littérature apocryphe bogomile, Cyrillomethodianum, XVII-XVIII, Thessalonique, стр. 143-153.

Tomislav Ž. Jovanović

\section{THE DEVIL'S ARGUMENT WITH JESUS CHRIST IN A SERBIAN COPY DATING FROM THE END OF THE $15^{\mathrm{TH}}$ CENTURY}

\section{Summary}

This apocryph with a dualistic basis is permeated with dialogues between the Devil and Jesus Christ. Their argument unfolds through a gradation, the two of them constantly trying to outsmart each other. Christ's views overpower all the tricks the Devil resorts to trying not only to defeat him but also to do him great harm. This apocryph is also known in Greek and Slavic copies. The oldest preserved copy in Serbian dates from the end of the 15 th century, and is to be found in the Nikoljac Monastery. This copy was used as the basis of this edition of the said apocryph, which is compared with five other copied versions of it.

Key words: apocryph, dialogue, Jesus Christ, the Devil 


\section{ПРИЛОГ}

Манастир Никољац, број 52, 1485/95. година, $66 \mathrm{a}-71 \mathrm{a}$.

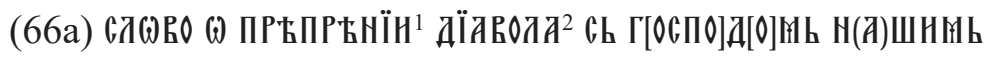
$\mathrm{I}(\mathrm{CO}) \mathrm{Y}(\mathrm{COHHL}) X(\mathrm{PH}) \mathrm{C}(\mathrm{TO}) \mathrm{Hll} \mathrm{L}: \sim^{3}$

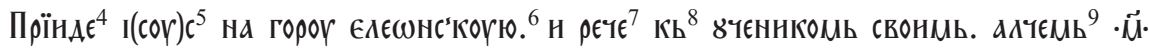

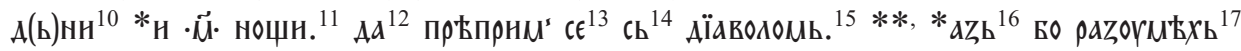

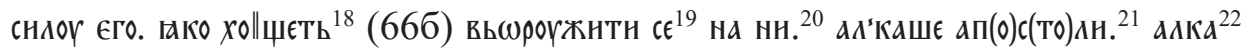

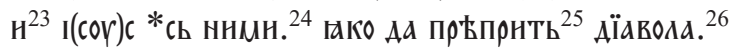

${ }^{1}$ Но: Сказанї̈ слово н прьпрьнїє, П: $\omega$ прђпрєнїю, С: прђпнранїє.

2 3: сотоннне, С: аньтнхрнстовом[ь].

${ }^{3} \mathrm{H}$, П, С + $($ (ть)ч(є Благословн), Но, 3 + Благословн (Ттьче.

${ }^{4}$ Н, П: Прнш[ь]дьшог, Но: Вьшьдь, С: прнБлнжншвм сє.

${ }^{5}$ Но: Господь, C: X(рн)с(т)оү $\leftrightarrow$.

${ }^{6} \mathrm{C}:$ маслннвю.

${ }^{7}$ П: глагола.

${ }^{8} \mathrm{H}, \mathrm{Ho}, \Pi-1$.

9 3: альтнмь, П + zдь, С: постнм сє.

${ }^{10} \Pi \leftrightarrow$.

11 * C + н постн се X(рнсто)с, $\ddot{\mu}$, А(ь)ны сь оүтеннкбы свонщн.

$12 *$ П: ПонєЖе Хоџ४.

${ }^{13}$ Но: прБпрнмо сє, П: прБпнратн сє, С: оүдолєть.

${ }^{14} \mathrm{C}-1$.

${ }^{15} \mathrm{C}$ : Аїавол8.

${ }^{16} \mathrm{H}-1$.

${ }^{17} \mathrm{H} \leftrightarrow$.

$18 *$ П: zанеже.

${ }^{19}$ П: вьорвжаєт сє.

${ }^{20} \mathrm{H}+$ н, П: нась + вєлМн. н.

${ }^{21} \mathrm{H}$ : оүченнццн + єго, П -2 + н, **Но ø.

${ }^{22}$ П: алкавь сє.

${ }^{23} \mathrm{H}, \mathrm{Ho}, \Pi \leftrightarrow, 3-1$.

${ }^{24}$ П: сь ४ченнкин свонМн.

${ }^{25} \Pi$ : прБПреть.

$26 *$ Но: н огтеннци єеГО .М. Аьнн н .М. ноштн, П + н, ${ }^{*} \mathrm{C}$ ø. 


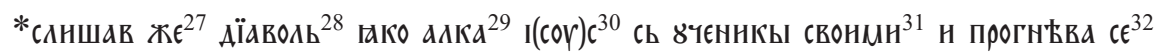

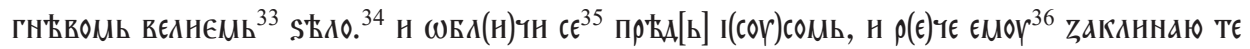

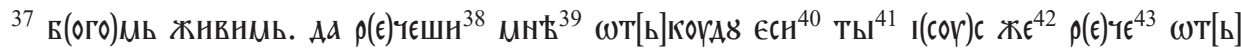

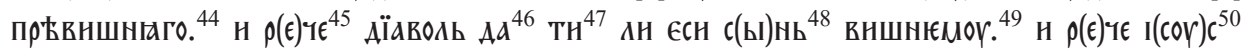

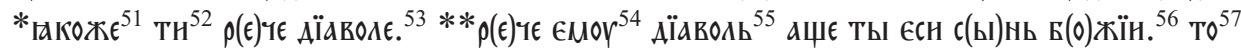

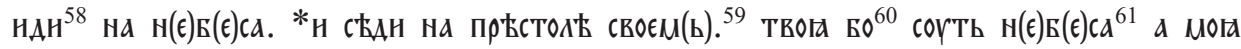
$\operatorname{Iec}(\text { Ть })^{62}$ Zемлґ. ${ }^{63}$

$27 *$ Но: Н чювь, П + сє.

${ }^{28} \mathrm{C}: 3,2,1$.

${ }^{29} \mathrm{C}:$ пос(Ть) Арьжнт(ь).

${ }^{30} \mathrm{C} \leftrightarrow$.

${ }^{31}$ Но: н втьнници него, П -6, С -3.

${ }^{32} \mathrm{H}$, Но, П, С: разгнћва сє, С + дїаволь.

${ }^{33} \mathrm{H}, \mathrm{Ho}, \mathrm{C} \leftrightarrow$, Но, С: вєк'ин, П -2.

${ }^{34} \mathrm{H}, \mathrm{C}-1$, Но: свониь, П: вєлмн.

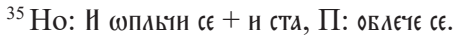

${ }^{36} \mathrm{H}+\mathrm{I}($ (о) $) c^{s}$, П: ка господв, C: I(соү)с.

${ }^{37} \mathrm{C}+$ AÏ̈воле.

${ }^{38} \mathrm{C}$ : скажєш(ь).

${ }^{39} \mathrm{H}$, П, С: мн, Н, П, 3, С $\leftrightarrow$, Но: да мн повъсн.

${ }^{40} \mathrm{C}$ : С.

${ }^{41} \mathrm{H}-1+$ н $\rho(\epsilon)$ ฯє Аїаволь а ты $\omega т[\mathrm{~b}] \kappa[0 \gamma]$ АоҮ єсн.

${ }^{42} \mathrm{H}, \Pi-1$, С: н.

${ }^{43} \mathrm{Ho}+$ єем8, C: $2,3,1$.

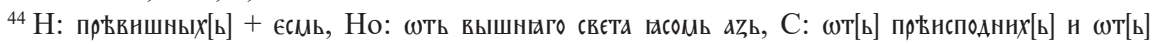
неБ( $(\epsilon)$ сныХ $($ ь) сндь.

${ }^{45} \mathrm{Ho}+$ IEML.

${ }^{46} \mathrm{C}-1$.

${ }^{47} \mathrm{Ho}-1, \mathrm{C}$ : то.

${ }^{48} \mathrm{H}: 4,2,1,3$, Но, C: 3, 1, 2, П: 4, 2, 3, 1.

${ }^{49}$ Но: пръвншнгему, П: прьвышнаго, С: внш'наго.

${ }^{50} \mathrm{Ho}$ : Ісогсь Же ретє еU४.

${ }^{51}$ П, С: raкo.

${ }_{52}^{52} \mathrm{C}$ : нстнну.

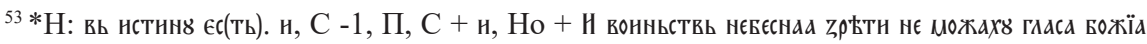
вь ныхь. Н.

${ }^{54} \mathrm{H}, \Pi, \mathrm{C}-1$.

${ }^{55} \mathrm{H}, \Pi+{ }_{\mathrm{Ad}}$.

${ }^{56} \mathrm{C}-5$.

${ }^{57} \mathrm{H}-1$, П: потто прндь сємо? нь, С: Аа.

${ }^{58} \mathrm{H}$ : Фтндн.

${ }^{59} \Pi, \mathrm{C} \leftrightarrow, \Pi+$ Понєжє.

${ }^{60} \Pi, \mathrm{C}-1$.

$61 * \mathrm{H} \varnothing$.

${ }^{62} \mathrm{C}: \operatorname{cor} \mathrm{T}(\mathrm{b})$.

${ }^{63} \mathrm{C}$ : zеманна. 


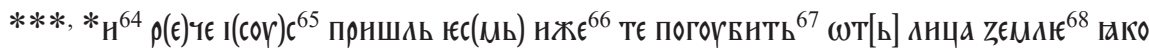

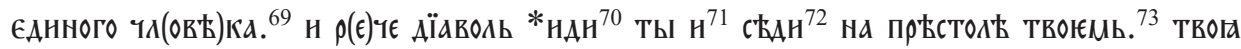

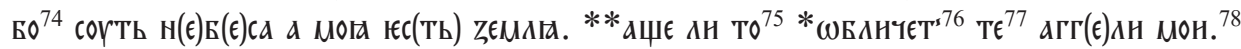

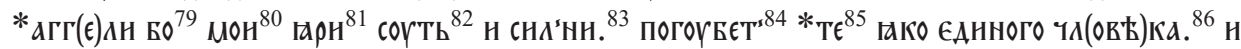

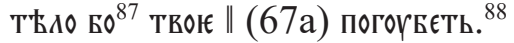

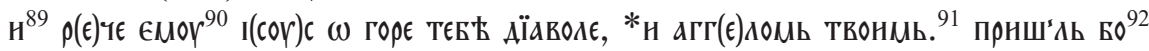

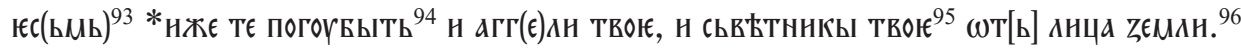

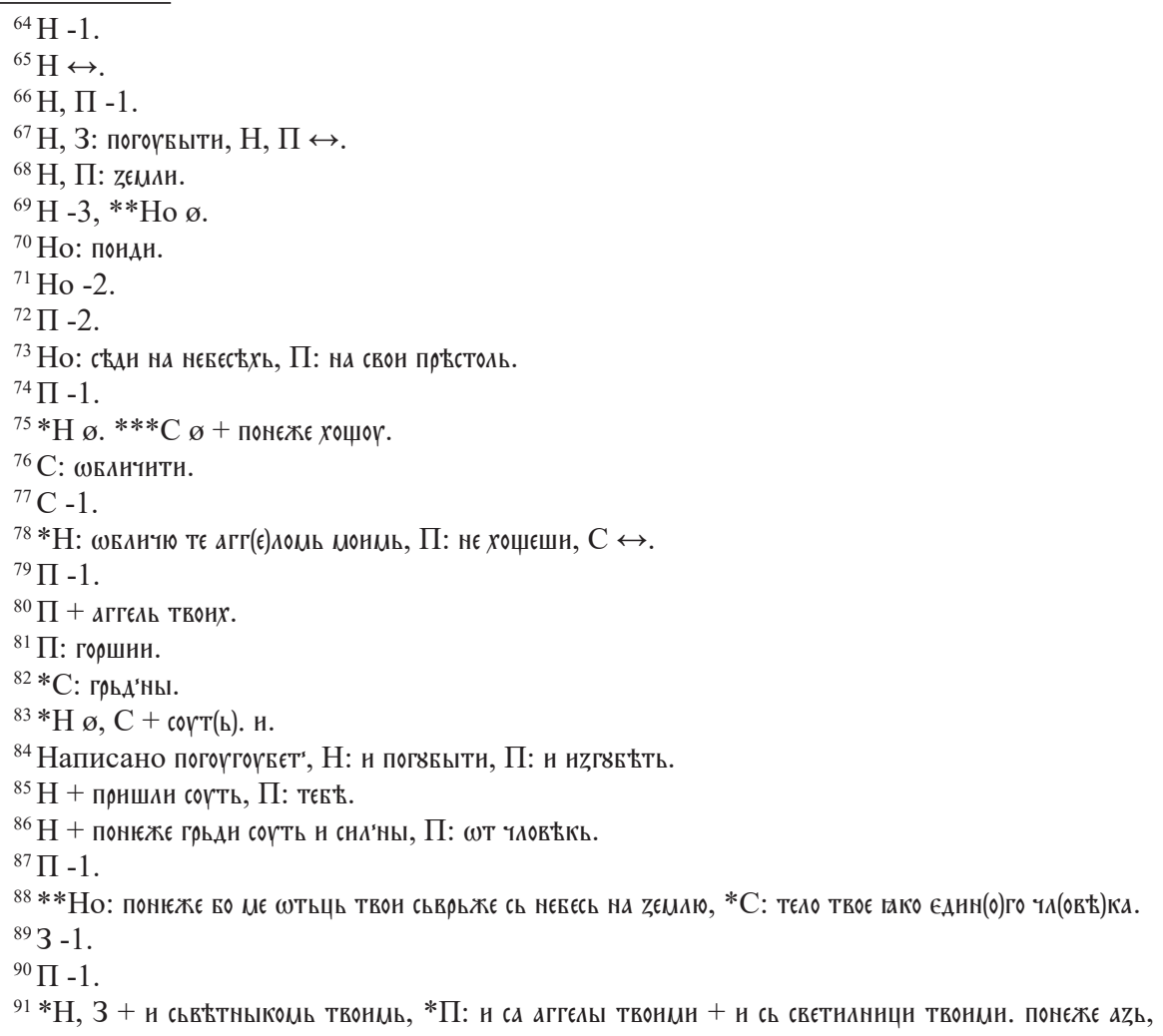
*C: тевБ paAï.

${ }^{92} \Pi, \mathrm{C}-1$.

${ }^{93} \mathrm{H}+$ на zємлю, Но -6 .

94 3: погвьн.

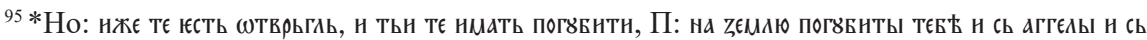
СветнАнНцН твонМн н потрББЫты.

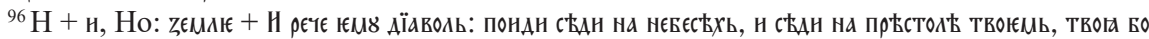

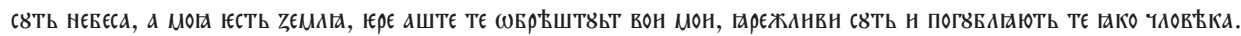

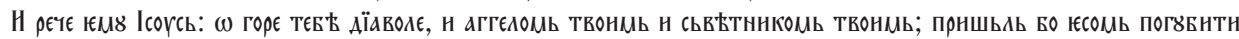

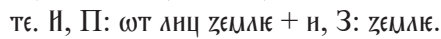




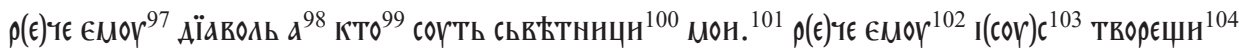

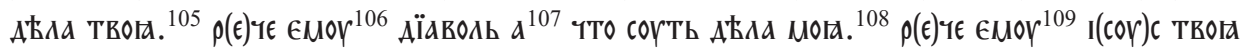

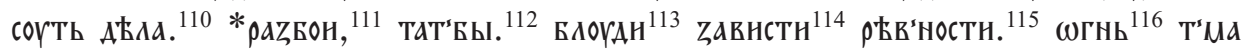

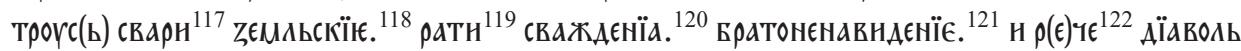

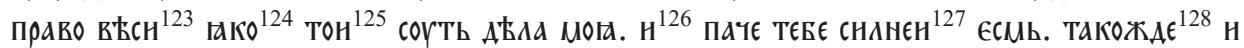

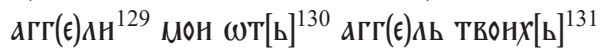

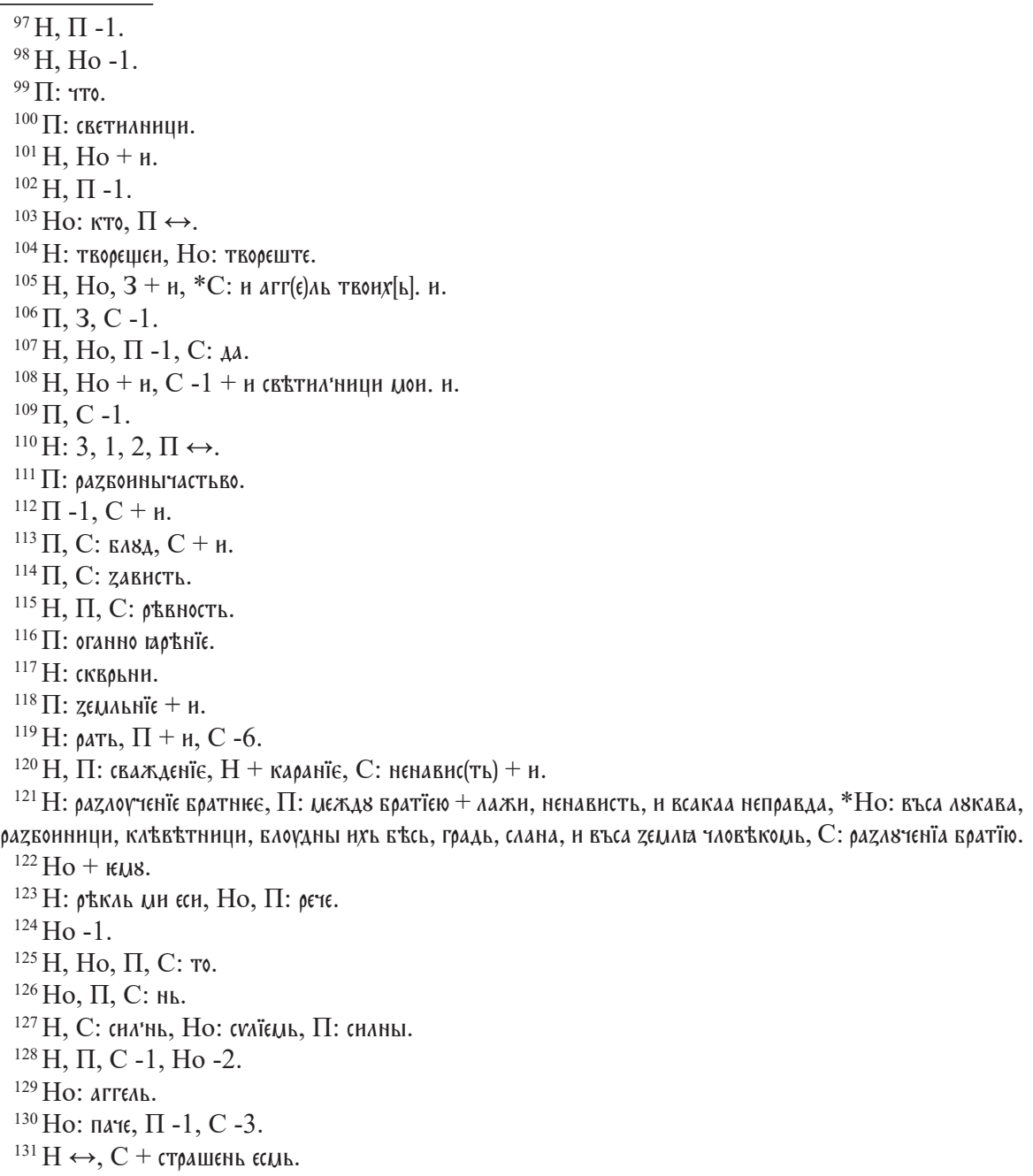




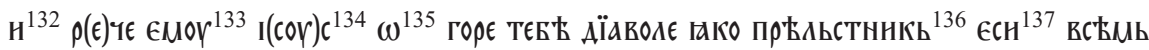

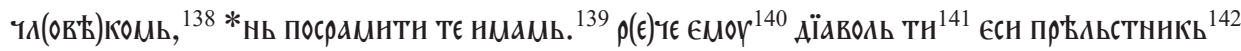

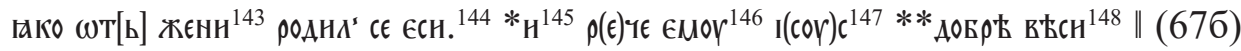

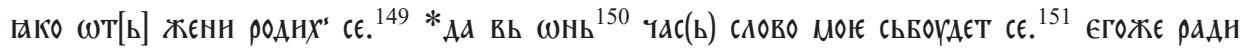

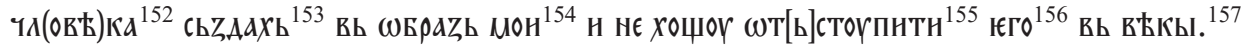

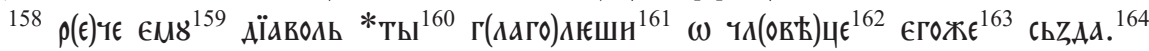

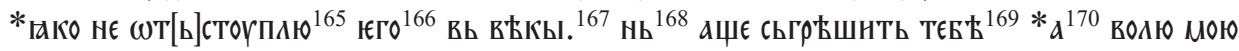

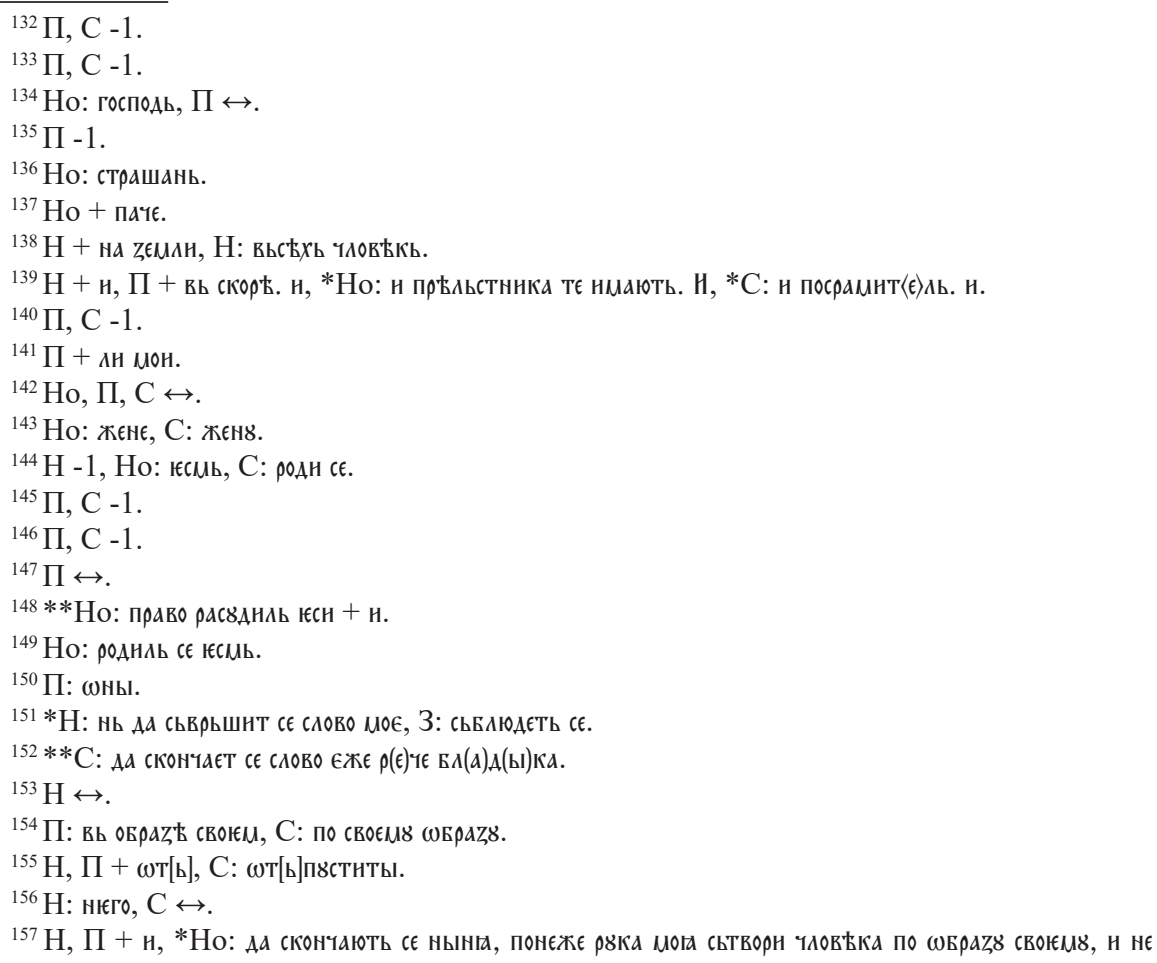




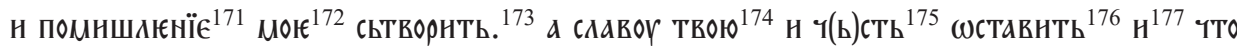

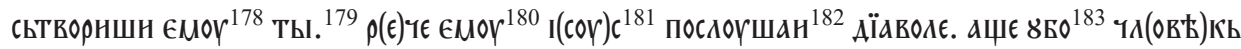

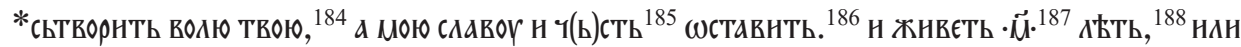

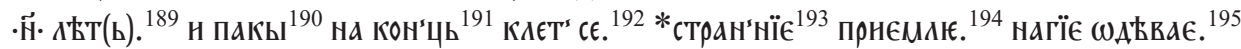

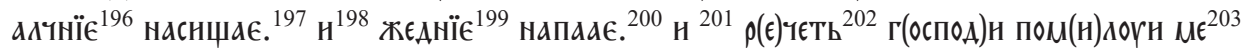

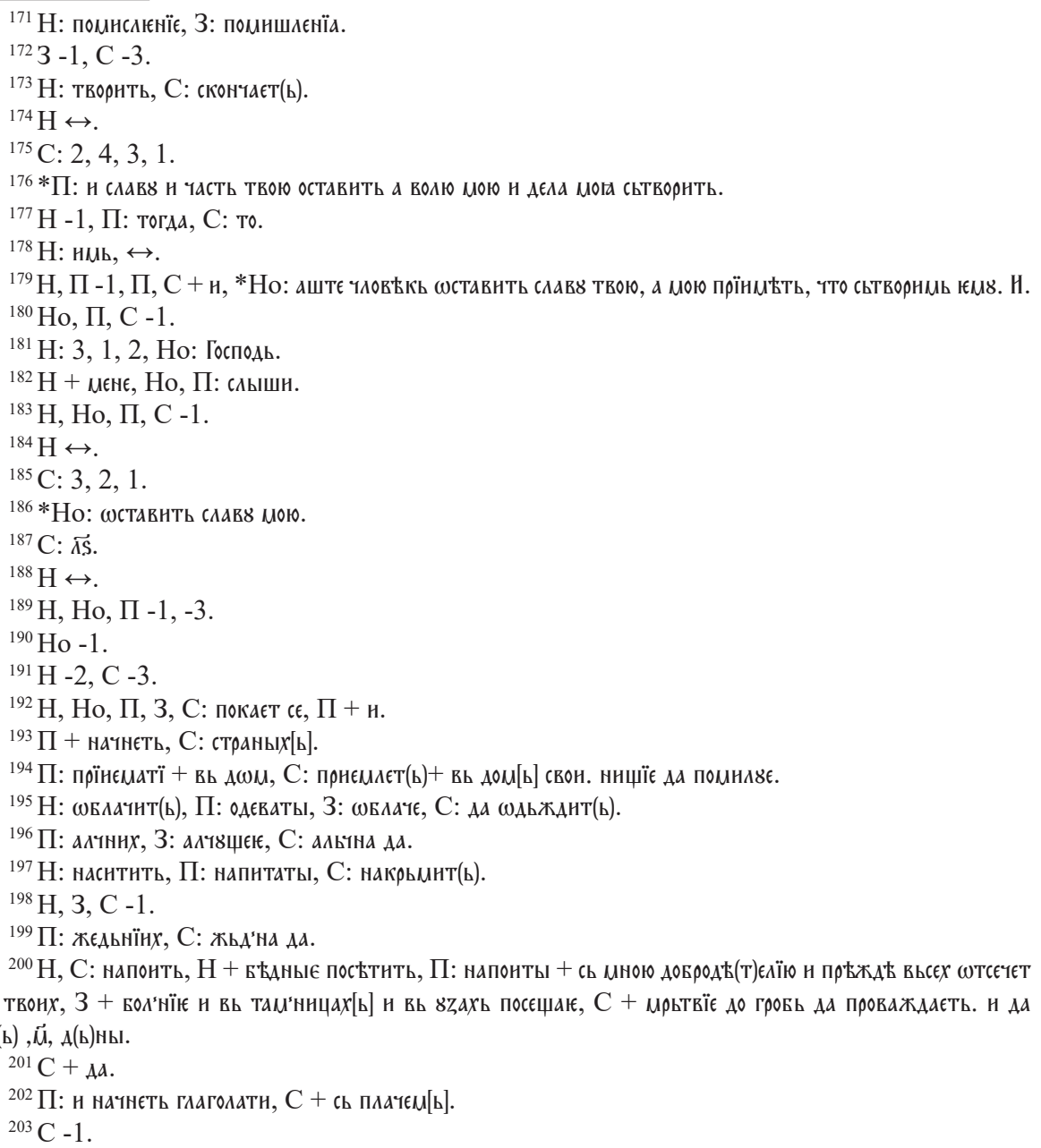




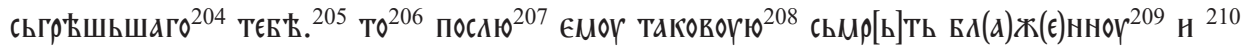

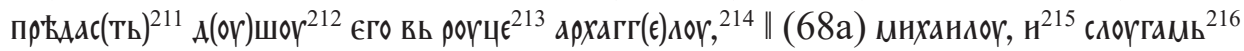

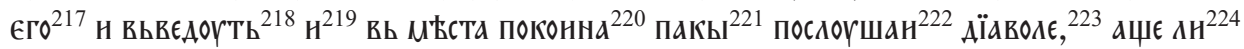

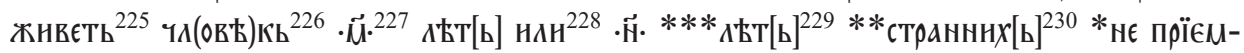
$\Lambda \leftarrow,{ }^{231}$ алчннх $[\mathbf{b}]^{232}$ не наснщає. ${ }^{233}$ нагнХь ${ }^{234}$ не

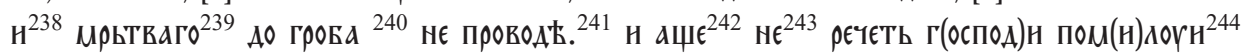

${ }^{204} \mathrm{H}$ : сьгрђшнх[ь], П, С: сьгрђшнвшаго.

${ }^{205} \mathrm{H}, \mathrm{C}:$ тн.

${ }^{206}$ П -1 + н того помнивюо н.

${ }^{207}$ П: пошлю.

${ }^{208} \Pi-1$.

${ }^{209} \Pi:$ влагую, $\leftrightarrow$.

${ }^{210} \mathrm{C}+$ того.

${ }^{211} \mathrm{H}$, П, 3: прњдамь, С: прєда, Н + н.

${ }^{212} \Pi-1$.

${ }^{213} \Pi-2, \mathrm{C}-4$.

${ }^{214} \mathrm{H}-5$.

${ }^{215} \Pi$ : сь.

${ }^{216}$ П: слугамн, С + да пондвть.

${ }^{217} \mathrm{H}$ : монмь, $\mathrm{C}-1$.

${ }^{218} \mathrm{H}$ : вьвњдог, П: 2, 3, 1.

${ }^{219} \mathrm{H}$ : єго, П, С -1.

${ }^{220} \mathrm{H}$, П: вь мҺсто поконно, С: вь пор8А(ь) + н.

${ }^{221} \mathrm{H}, \Pi-1, \Pi+$ н $є щ \epsilon$.

222 П: слышн, С + мене.

223 * Но: таковомв подамь Балгоүю сьмрьть, 3: сотоно, С: дїаволн.

$2243+$ ж⿻.

${ }^{225} \mathrm{H}$ : жнвь.

${ }^{226} \mathrm{Ho}-1, \mathrm{C} \leftrightarrow$.

${ }^{227} \mathrm{C}:, \overrightarrow{\mathrm{OS}}$, .

${ }^{228} \mathrm{C}:$ нАA + Сє нє покАєТт.

${ }^{229} \mathrm{H}, \Pi-1, \mathrm{C}-2$.

${ }^{230} \mathrm{H}$ : стран'ныє, 3: стран(ь)нн.

231 *С: нє вьвєАєТ(ь) вь дом[ь] свонм[ь]. н ннщнХ[ь] нє помнд४є.

${ }^{232} \mathrm{H}$ : альчныє.

${ }^{233}$ С: накрьмнт(ь).

${ }^{234} \mathrm{H}$ : нагне, 3, С: нагн.

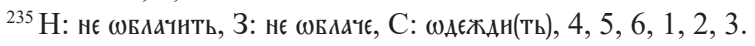

${ }^{236} \mathrm{H}:$ жєдныє, 3: жєА[ь]ннн, С: жьдннх[ь].

${ }^{237} \mathrm{H}$ : напонть, С: напон.

${ }^{238} \mathrm{H}, \mathrm{C}-1$.

${ }^{239} \mathrm{C}$ : мрьтвї̈.

${ }^{240} \mathrm{C}+{ }_{\text {Aa }}$.

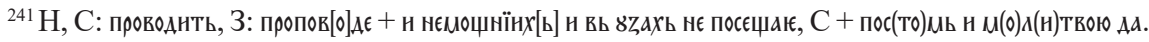

${ }^{242} \mathrm{H}-1, \mathrm{C}-2$.

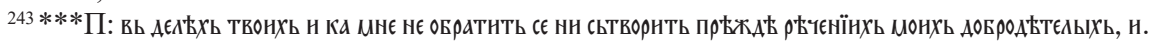
${ }^{244} \Pi+$ н простн. 


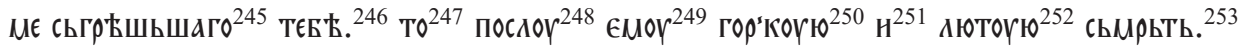

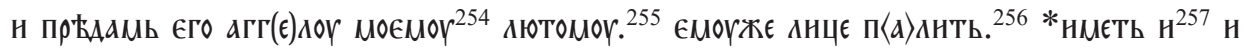

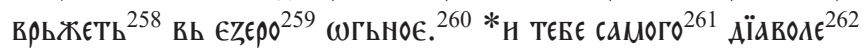

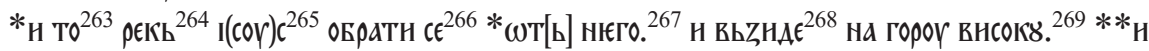

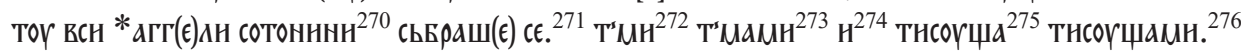

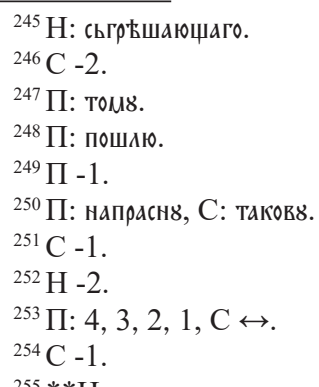

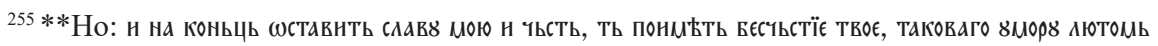
сьмрьтїю; н лютомоү агтел४, П -1, С: ФгнБн8.

${ }^{256}$ Написано полнть, Н + шгнємь, Но: горнть, П: пламєноє, 3: полнть + н, С: вьzгорнт сє.

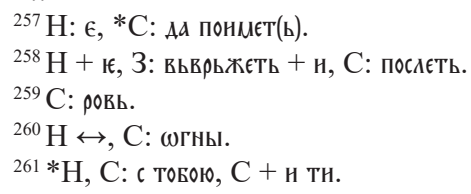

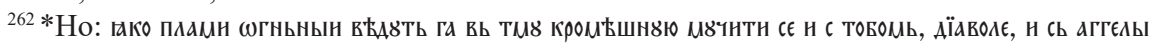

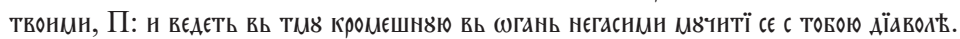

${ }^{263} \mathrm{H}$, П: сє.

${ }^{264} \mathrm{H}$, Но: г(лаго)лавь.

$265 *$ С: того радан разгнБвав сє Аїавол(ь). н.

266 3:

${ }^{267} \mathrm{C}$ : I(cor)ca.

$268 *$ Но: Аїаволь.

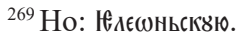

$270 * \mathrm{H}$ : Аїаволїє, П: дїаволы.

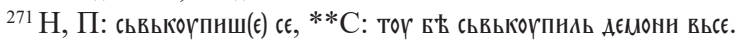

${ }^{272} \mathrm{H}$, П: тиt.

${ }^{273} \mathrm{H}:$ тuа.

${ }^{274} \mathrm{C}-1$.

${ }^{275} \Pi$, С: тнс8щє.

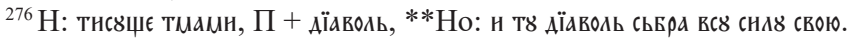




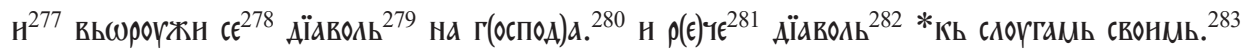

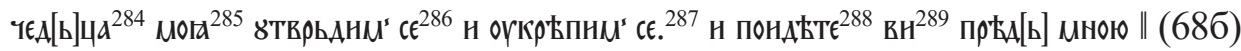

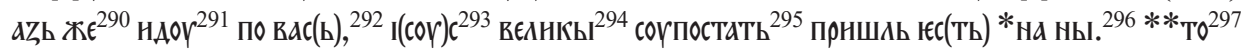

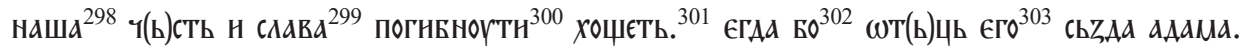

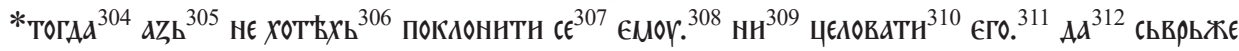

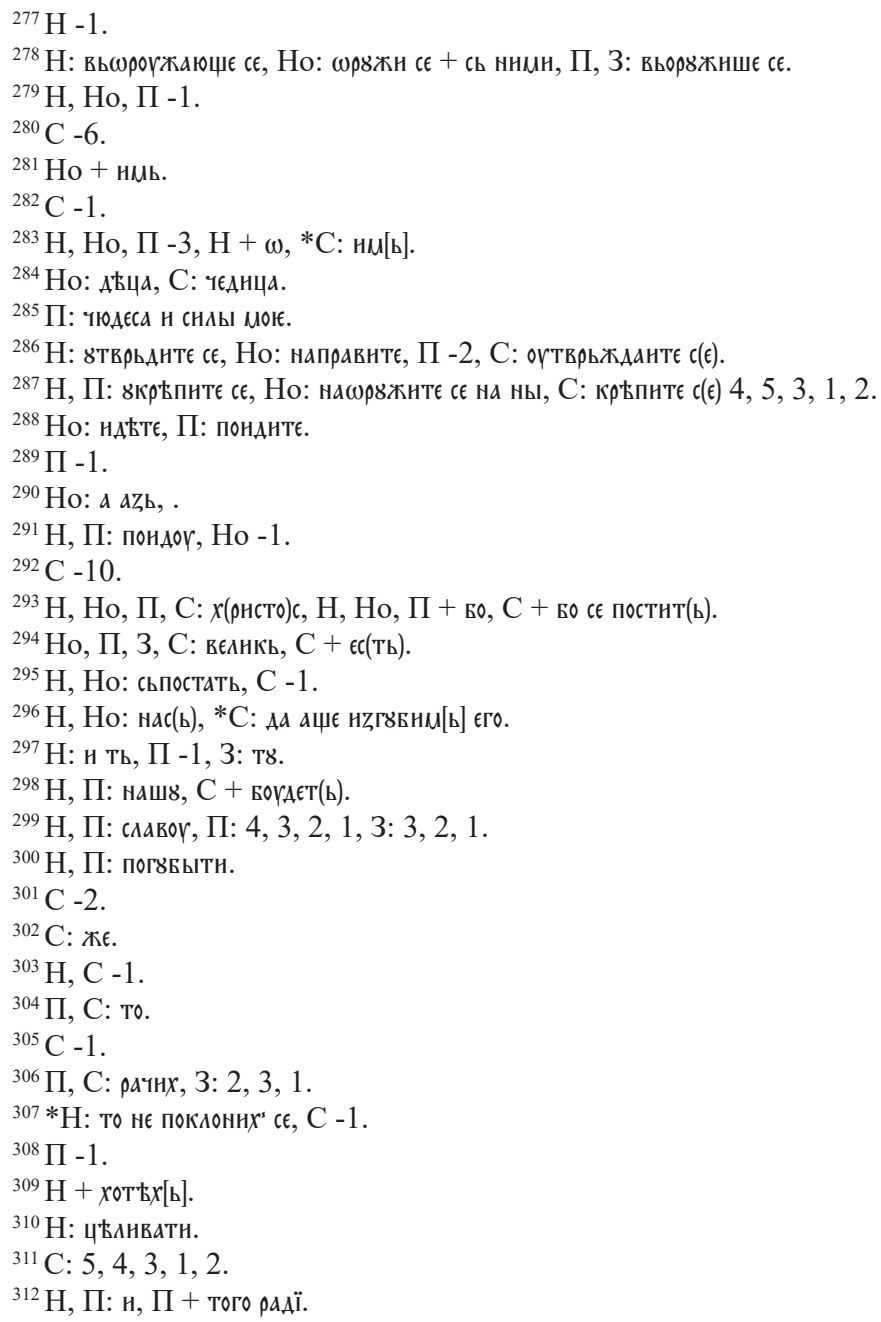




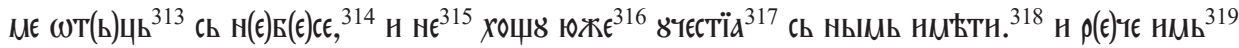

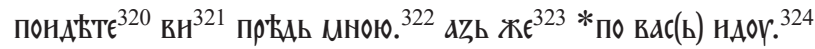

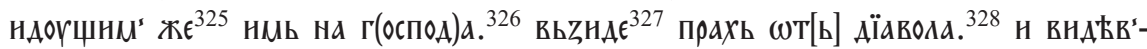

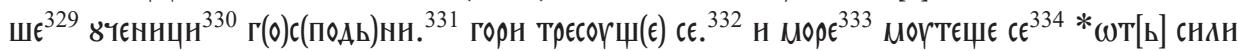

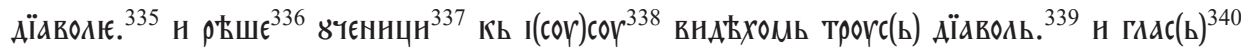

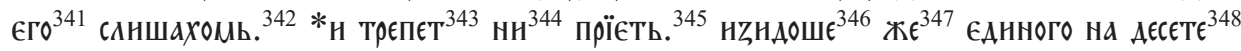
пьпрнща. 349

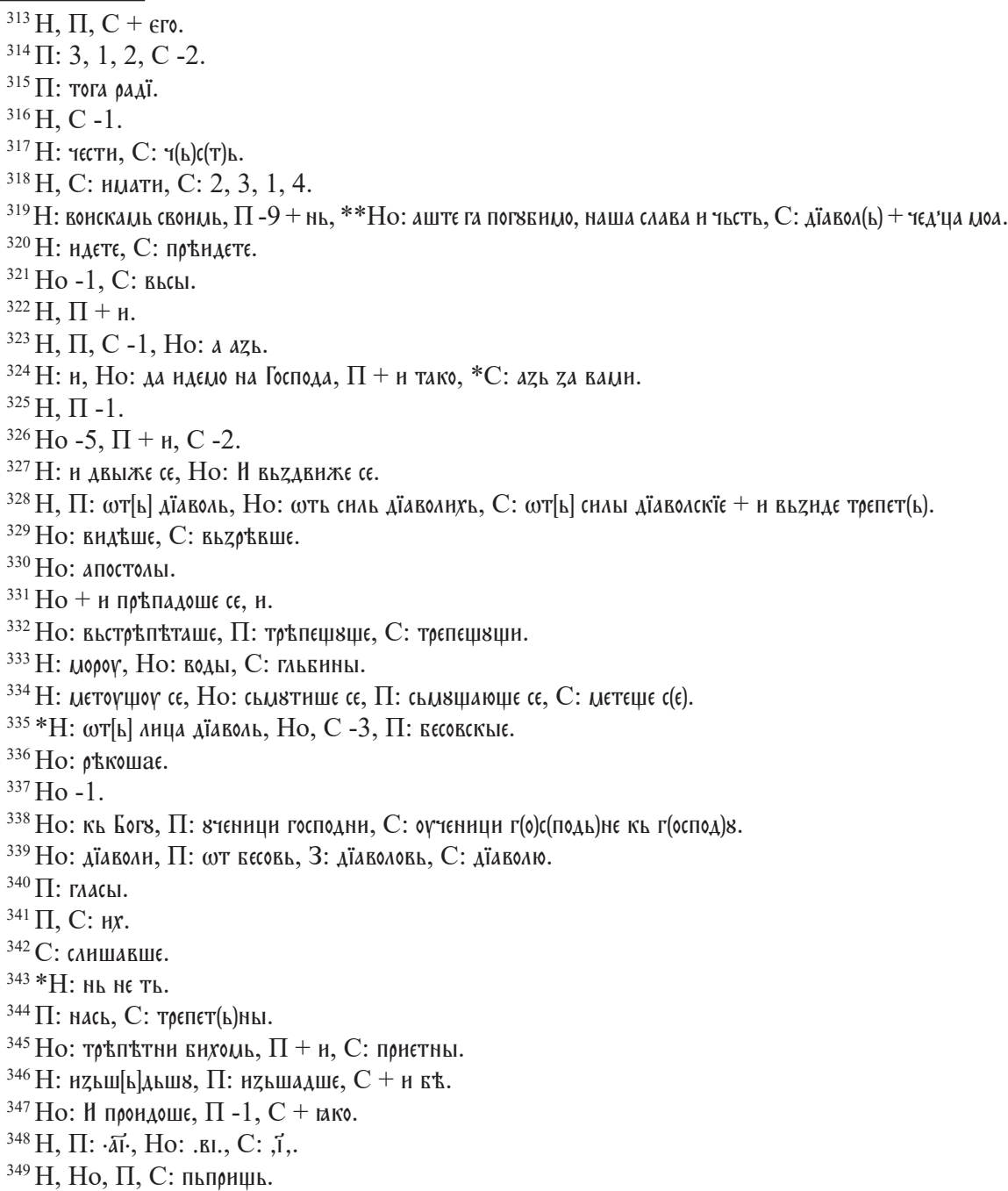




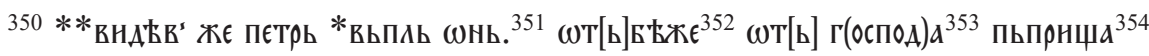

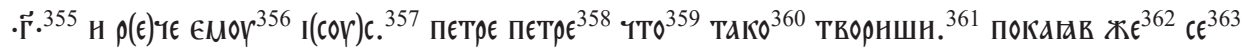

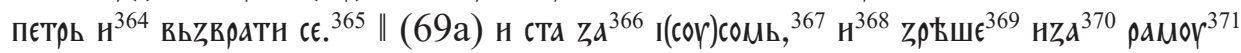

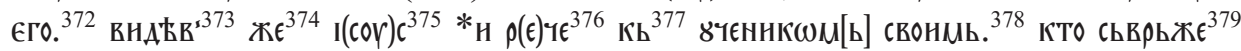

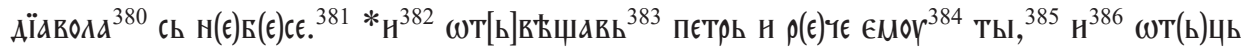

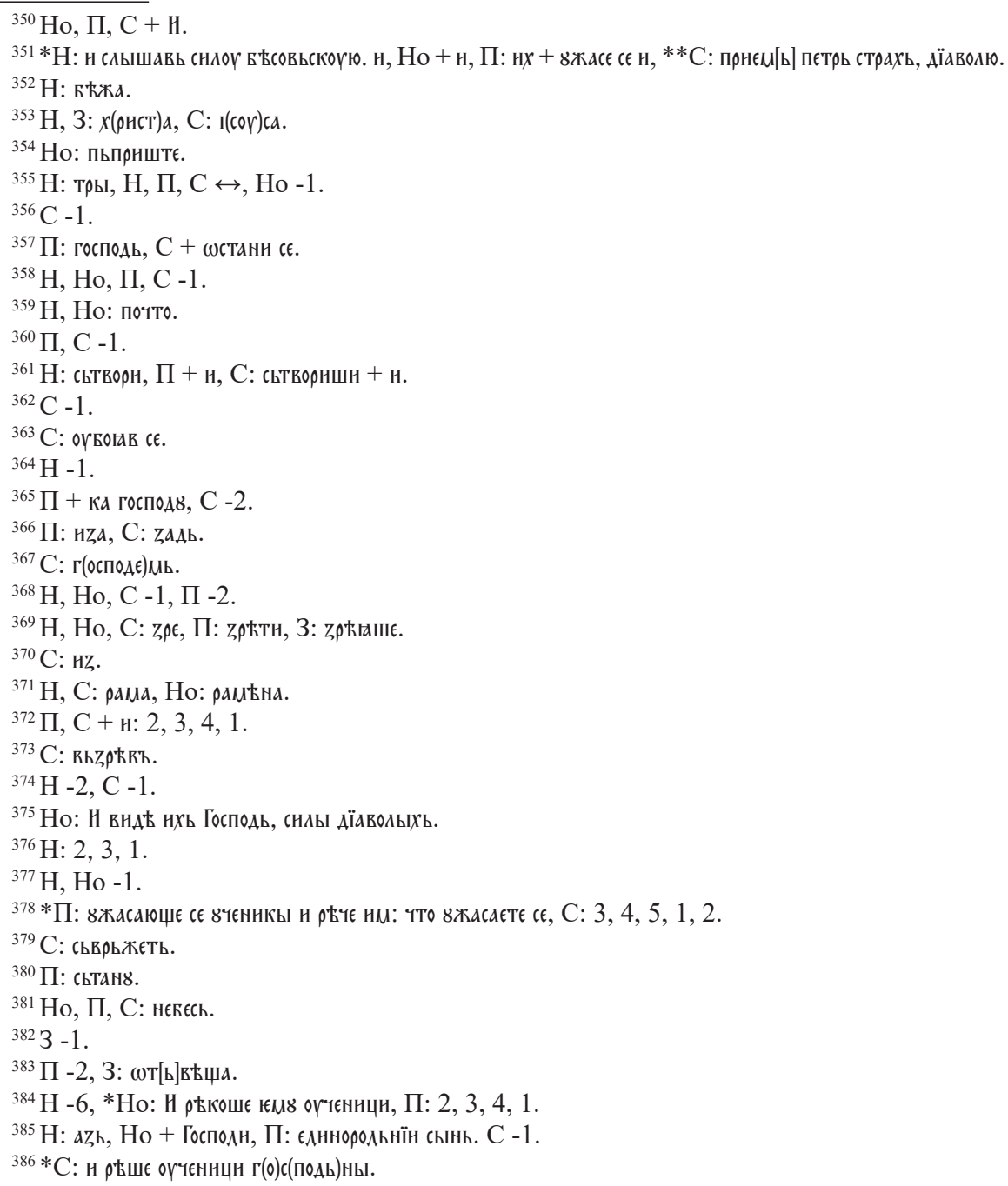




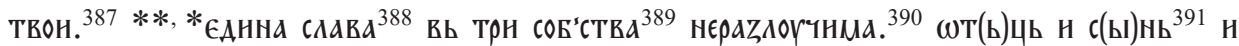

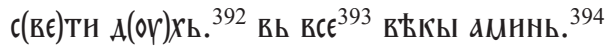

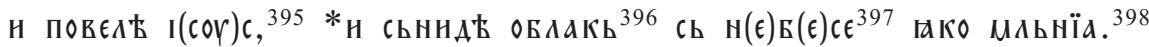
* н вьзеть ${ }^{399}$ Аїавола, ${ }^{400}$ н

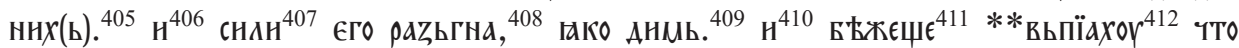

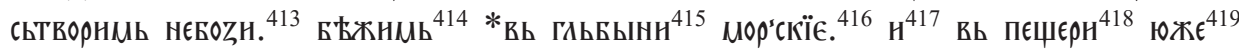
кнєZа н(А)шєГо,

\footnotetext{
${ }^{387} \mathrm{H}-1+$ ЕАНна ч(ь)сть н.

${ }^{388} \mathrm{H}+$ н СниА н Еднно.

${ }^{389} \mathrm{H}:$ г[о]спод[ь]ство, С -3 .

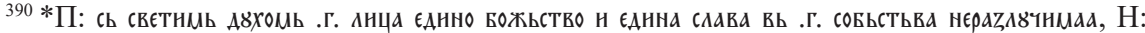

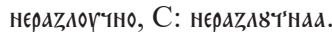

$391 * *$ Hо ø.

${ }^{392} \mathrm{C}-6$.

${ }^{393} \mathrm{H}, \mathrm{C}-1$.

${ }^{394}$ Но, П -4, С: вБком[ь] + то рєк'ш8 пєтр8.

${ }^{395} \mathrm{H}, \mathrm{Ho,} \mathrm{C:} \mathrm{Г(ОспоА)ь.}$

396 *Н: (Блакоү прїнтн, П: прїнты оБлак8.

${ }^{397}$ П, З: сь неБєСь, П + на zєМлю, *С:

${ }^{398}$ Но -7, П: миьнїн, С: миьнїє.

${ }^{399}$ Но: вьсхнтн, П: вьсхнтнты, ${ }^{*}$ : : сь н $(\epsilon)$ в $(\epsilon)$ сь свєZаты.

${ }^{400}$ П: сьтану.

${ }^{401} \mathrm{H}+\epsilon г о$, Но + га, П, С: оБєснты.

${ }^{402} \mathrm{C}$ : стрьмоглав8.

${ }^{403}$ Но, П: за нозЊ, П + єГо, С: пєтетє 2, 3, 1.

${ }^{404} \mathrm{C}$ : вь.

${ }^{405} \mathrm{H}$, П + н выс(ть) тако, Но -3.

${ }^{406}$ Ho: a.

${ }^{407} \mathrm{H}$ : снлог.

${ }^{408}$ Но: пов Бгошє + (ть Анца господнга.

${ }^{409} \mathrm{Ho}+$ гако днцъ

${ }^{410} \mathrm{Ho}-1$.

${ }^{411} \mathrm{H}, \mathrm{Ho}, \mathrm{C}$ : въжахог, Но + вь ПБштере.

${ }^{412} \mathrm{H}$ : вьпїющє.

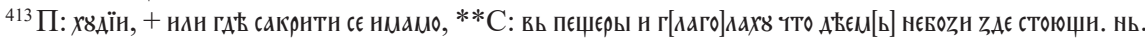

$414 \Pi-1$.

415 З: БЬ ГАЬБННЕ.

416 *Н: вь ГАьБыноү мор'скоүю, П: вь ГАьБннах морскых.

417 П: нлн, С -2 .

${ }^{418}$ П: вь пєщєрах: $5,6,4,1,2,3$.

${ }^{419}$ П + Бо, С -1 + н вь пропастеХ[ь] zемиьннХ[ь]. понєжє Бо.

${ }^{420} \mathrm{C}+$ zа пете.

${ }^{421} \mathrm{C}$ : вь.

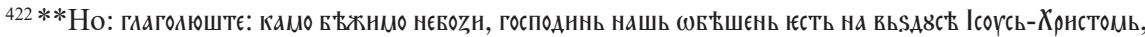

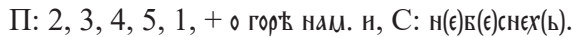




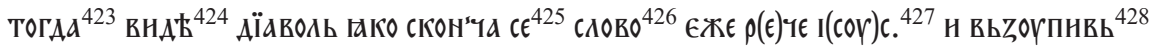

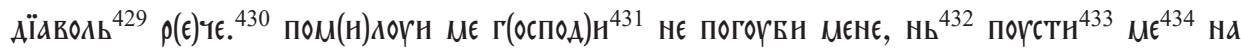

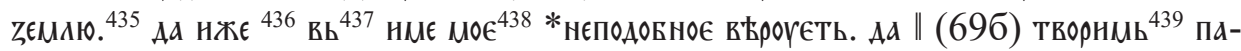
костн ${ }^{440}$ таковниъ. ${ }^{441}$ Ad $^{442}$ всн

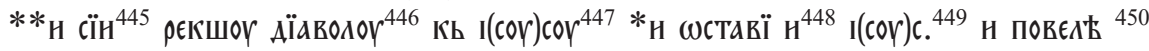

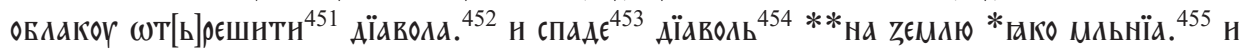

${ }^{423} \mathrm{H}+$ жє, Но: Н кто.

${ }^{424}$ Но, П, З: вндьвь.

${ }^{425}$ Но: сьврьшн сє.

${ }^{426} \mathrm{H}+\epsilon$, $\mathrm{O}, \mathrm{Ho}-1$.

${ }^{427}$ П: хрнстос, $\leftrightarrow$, С: Г(оспоА $)$ ь + кь Аїавон8.

${ }^{428}$ Н: вьзьпїн, Но: вьдвпн, С -2.

${ }^{429} \Pi-1$.

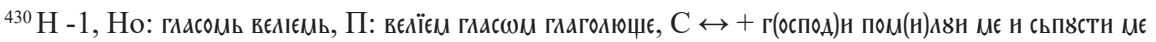

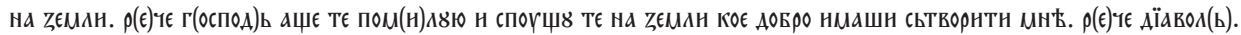

${ }^{431} \mathrm{Ho}+\mathrm{H}, \mathrm{C}: 3,1,2$.

${ }^{432} \mathrm{Ho}$.

${ }^{433} \mathrm{H}$, Но, П, З: спвстн.

${ }^{434} \mathrm{C}:$ Mене.

${ }^{435} \mathrm{C}:$ zєМАн.

${ }^{436} \mathrm{C}+$ вЂровашє.

${ }^{437}$ Ho -1 .

${ }^{438}$ Но: твоє.

439 *Но: прндовьть н творнть, П: твору нм.

${ }^{440} \Pi+$ н.

${ }^{441}$ Но -1, П: таковы, *С: нєдоС(то)нноє. Аа нм[ь] повєАУ.

${ }^{442} \Pi-1$.

${ }^{443}$ Но, П, С: овратєть сє.

${ }^{444} \mathrm{C}: 3,1,4,5,2$.

${ }^{445} \mathrm{H}$, П: сє, Но: то.

446 3: Аї̈ав0八ь.

${ }^{447}$ Ho -2 .

$4483-1$.

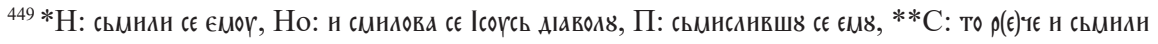
cє $\Gamma($ (ОСПОА) $)$.

${ }^{450} \mathrm{C}+\mathrm{r}($ (оспоА $) \mathbf{b}$.

${ }^{451}$ Но: раздроүшнтн.

${ }^{452} \mathrm{H}: \mathrm{\epsilon}$ Г०, $\mathrm{C}-1$.

${ }^{453}$ П, C: падt.

${ }^{454} \mathrm{H}$, П -1, Но: спвстн га.

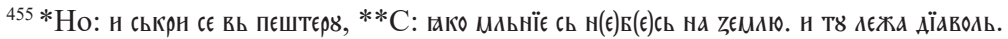




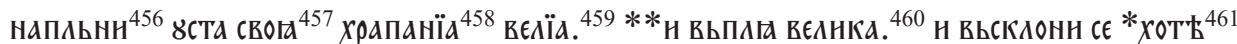
ПоєТн $\mathrm{CE}^{462}$ Г(ОСПОА $)$ a. ${ }^{463}$

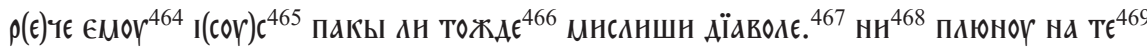

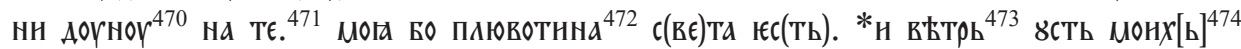

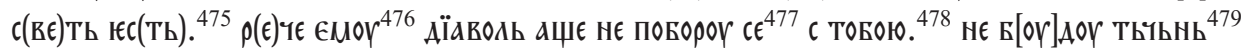

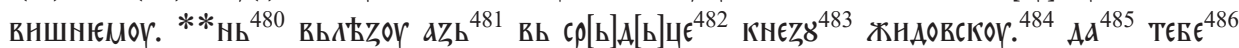
* на кр(ь)сте ${ }^{487}$ прнгвоZанть ${ }^{488}$ н 8норет ${ }^{489}$ Te. $^{490}$

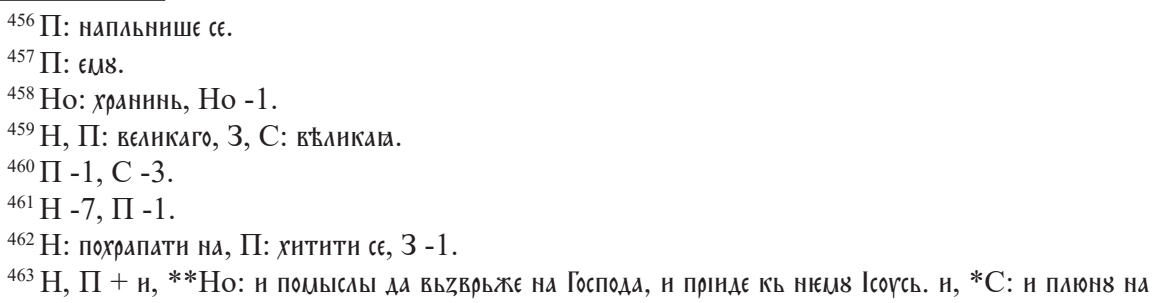
Г(ОСПОА) а н А'ХН8 На Нь. н.

${ }^{464} \mathrm{C}-1$.

${ }^{465} \mathrm{Ho}-1, \mathrm{C}$ : г(ОспоА $)$ ь.

${ }^{466} \mathrm{Ho}+$ слово, $\mathrm{C}-1$.

${ }^{467}$ Но + н ретє єе४ дІаволь, П + н нд४, С $\leftrightarrow+$ на Мє. н $\rho(\epsilon)$ IE $\Gamma($ (OCח०А $) \mathbf{b}$.

${ }^{468} \mathrm{C}:$ не.

${ }^{469} \mathrm{H}-2$.

470 3, C: А8хн8.

${ }^{471}$ Но + аште Быхь н плюн8Аь, П -4.

${ }^{472}$ Н, Но, П: слына, С: слнн'ка, П: 3, $2,1$.

${ }^{473} \mathrm{H}, \Pi+\omega \mathrm{T}[\mathbf{b}]$.

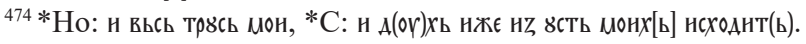

${ }^{475} \mathrm{H}-2, \mathrm{H}$, П, C + н, Но + Н пакы.

$4763, \mathrm{C}-1$.

${ }^{477}$ Но: вору сє.

${ }^{478}$ Но: сь товомь.

${ }^{479}$ Но: подовань, С: тоүчен(ь).

${ }^{480} \mathrm{C}:$ н.

${ }^{481} \mathrm{H}$, П, C -1 .

${ }^{482} \mathrm{C}$ : ср(ь)А(ь)цин.

${ }^{483} \mathrm{H}$ : канафнно, С: канафе.

${ }^{484} \mathrm{H}$, П, С: жндовьскомог, П: $3,4,1,2+$ н сьтвору.

${ }^{485} \mathrm{C}:$ та.

${ }^{486} \mathrm{H}, \mathrm{C}:$ T $\epsilon$.

${ }^{487} \mathrm{H}$ : на кр(ь)сть, ${ }^{*}$ С: нивт(ь) н мвчють тє н.

${ }^{488} \mathrm{H}$, П: прнгвоZАєТь, С: распнєт' те.

489 3: вморнт", С: оүмрьтв8т".

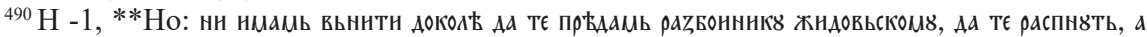
AЮAIE АA TE ПрОАAЕTЬ. 


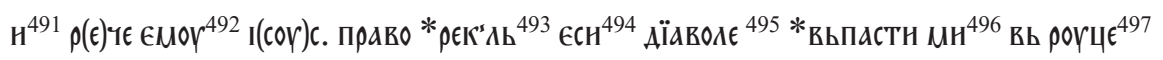

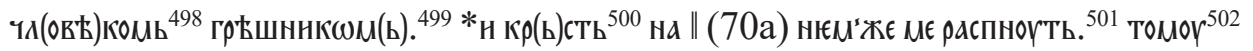

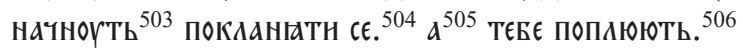

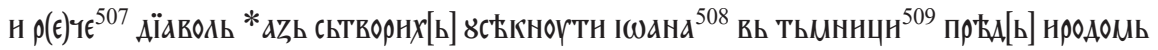

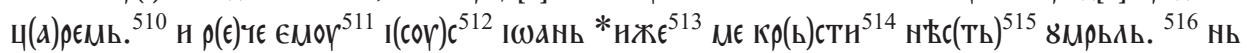

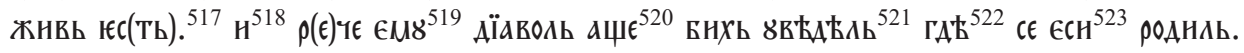

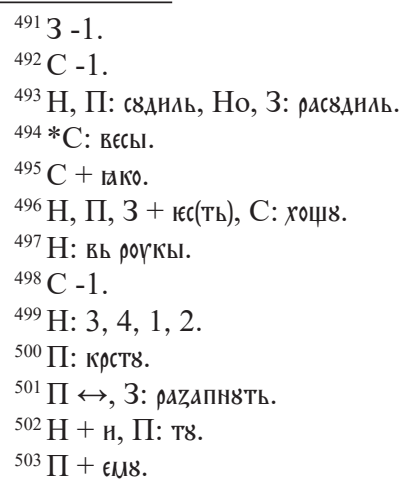

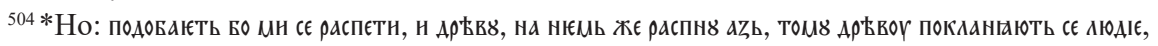
П, 3: кАанатн сє.

${ }^{505} \mathrm{H}:$ н, П + на.

${ }^{506}$ Но: тєрають, П: вьспдвють, ${ }^{*} \mathrm{C}:$ кр(ь)сть хощ४ сьтворнты мнћ. н том४ хощоүт(ь) вьсн покдоннтн сє а тевБ ФПаюты дїаволє.

${ }^{507} \mathrm{Ho}+$ เєM8.

${ }^{508} \mathrm{H}, \Pi, \mathrm{C} \leftrightarrow, \mathrm{C}+\kappa \rho(\mathrm{\iota}) \mathfrak{c}(\mathrm{TH}) \mathrm{T}(\epsilon) \Lambda$ ґа.

${ }^{509} \mathrm{H}, \Pi, \mathrm{C}-2$.

${ }^{510} \mathrm{H}-1$, *Но: азь вьнндохь вь срьдце н Iродог цару да I

${ }^{511} \mathrm{H}, \mathrm{C}-1$.

${ }^{512} \mathrm{C}: \mathrm{r}($ (оспоА) $\mathrm{b}$.

${ }^{513} \Pi:$ жє.

${ }^{514} \Pi+$ нь, ${ }^{*} \mathrm{C}: \kappa \rho(\mathrm{b})(\mathrm{TH}) \mathrm{T}(\mathrm{\epsilon}) \boldsymbol{\Lambda} \mathrm{b}$.

${ }^{515} \mathrm{C}:$ нє.

${ }^{516} \mathrm{C}+\epsilon(\mathrm{Tb})$.

517 *Но: же менє Іесть, С + н АО Н(Ы)нга.

${ }^{518} \Pi-1$.

${ }^{519} \Pi, \mathrm{C}-1$.

${ }^{520} \Pi:{ }_{A d}, \mathrm{C}+\mathrm{T \epsilon}$.

${ }^{521}$ Н, П: вндҺль, Но: zналь, С: zнағаль.

${ }^{522}$ П: КОГАА.

${ }^{523} \mathrm{H}$, П, С: сн, Но: Ієсть, П: ↔. 


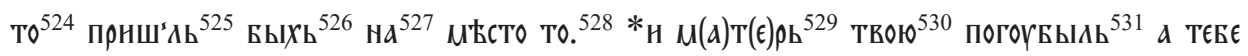

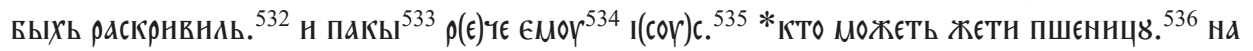

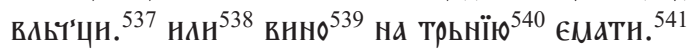

н не

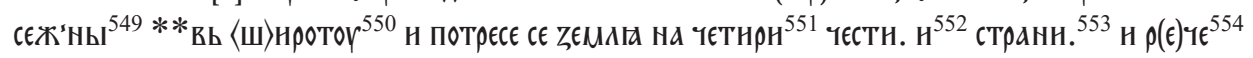

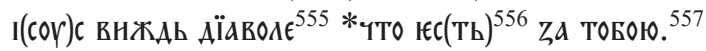

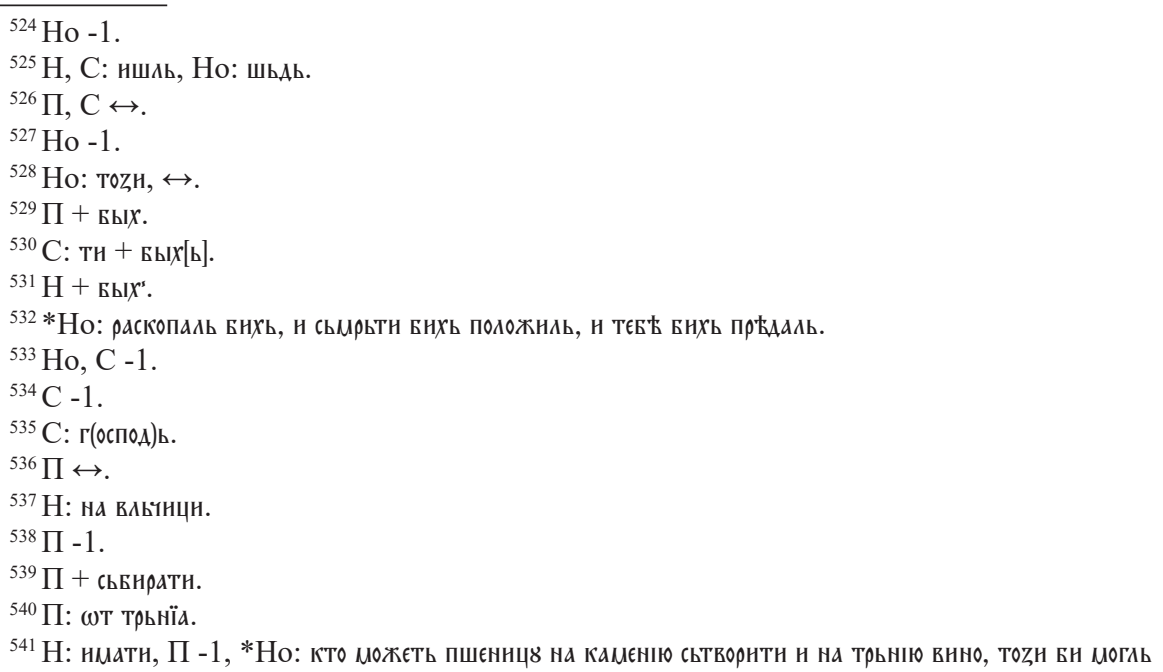

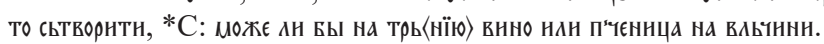

${ }^{542} \mathrm{C}-1$.

${ }^{543}$ Но, П + ннчєеожє, П -1, С + ннчто.

${ }^{544} \mathrm{C}: \rho(\epsilon) \Psi \epsilon$.

${ }^{545} \mathrm{C}$ : г(ОспоА $)$ b.

${ }^{546}$ Ho: zemale.

${ }^{547} \Pi$ : раст8пнтн сє, $\mathrm{H}, \Pi \leftrightarrow$.

${ }^{548} \mathrm{C}$ : , п́,.

${ }^{549}$ Н: сєЖнь, Но: сєжань, П: сєЖаннх, С: съж'ны.

${ }^{550}$ Написано жнротог, Но: вь шнрнну.

5513 :

${ }^{552} \mathrm{H}, \Pi$ П -2, Но -8.

${ }^{553} \mathrm{H}$, Но: странъ, П + раст8пн сє по повєАБнїю Божїю.

${ }_{554}^{55} \mathrm{Ho}+$ เем8.

${ }^{555} \Pi+$ вєАнчастьво.

${ }^{556} \Pi-2$.

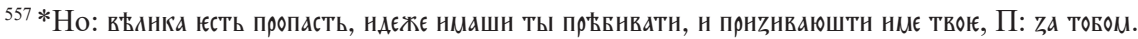




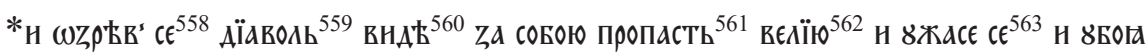

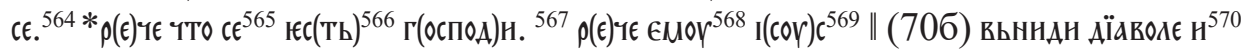

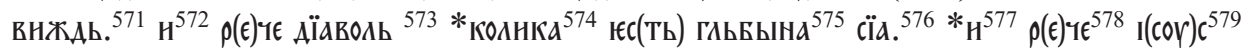

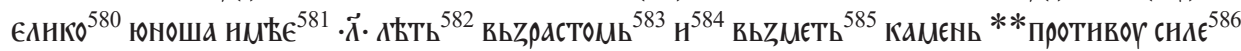

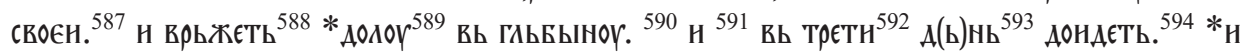

${ }^{558} \mathrm{H}$, П:

${ }^{559} \mathrm{H}, \Pi+\mathrm{H}$.

${ }^{560} \Pi$ : вндҺвь.

${ }^{561} \mathrm{H}: 3,1,2$.

${ }^{562}$ П: вєАнКгю.

${ }^{563} \mathrm{H}-3$, П: жасє сє, * Но: Н то вндьвь.

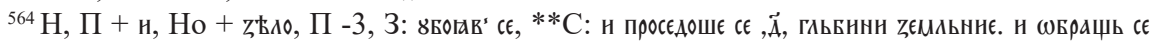
дїавоЛ(Ь) н вндє н $\rho(\epsilon)$ чє тТО єе(ТЬ) єє Г(ОспоА)Н.

${ }^{565} \mathrm{H}-1$.

$5663, \mathrm{C} \leftrightarrow$.

${ }^{567} \mathrm{H}$, П, C + н.

${ }^{568} \Pi, \mathrm{C}-1$.

${ }^{569} \mathrm{C}:$ г(ОспоА) ь.

${ }^{570} \mathrm{C}:$ Aa.

571 * Но ø, П: 3, 1, 2, С: вндншь + тто єе(Ть).

${ }^{572} \Pi-1$.

${ }^{573} \mathrm{C}+\Gamma($ (оспоА $)$ H.

${ }^{574} \mathrm{C}$ : колнкко.

575 З: гАвБнна.

576 *П: ГАьБОКО Аы Іест сє, С: сєМ४ $\leftrightarrow$.

${ }^{577} \Pi, \mathrm{C}-1$.

${ }^{578} \mathrm{Ho}+$ เеM8.

${ }^{579}$ Но, С: Господь, П + єщ४.

${ }^{580}$ Но: колнко + можеть, П: Быбьшїн.

581 *Н: ґако да Боүаьть юноша, Но -1, П:

${ }^{582}$ Но:.г.-А'Ттьнь, C: 2, 3, 1.

${ }^{583} \mathrm{C}-1$.

${ }^{584} \mathrm{Ho}-2, \Pi+{ }_{\text {Aa. }}$

${ }^{585}$ Но: въzетн.

${ }^{586}$ П: снлы.

${ }^{587}$ П: СRofle.

${ }^{588}$ П: вьврьжєть, С + н Аєтнт(ь).

${ }^{589} \mathrm{C}-1$.

${ }^{590} \mathrm{C}+, \vec{\Lambda}, \Lambda \mathrm{BT}(\mathrm{b})$.

${ }^{591} \mathrm{C}+$ Tako.

592 3: , $\vec{\Gamma} .$.

${ }^{593} \mathrm{C}-3$.

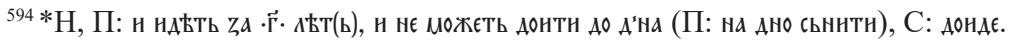




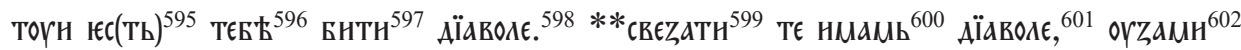

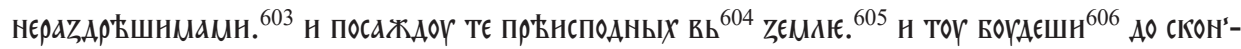
чанїа в"кка сєГо. ${ }^{607}$

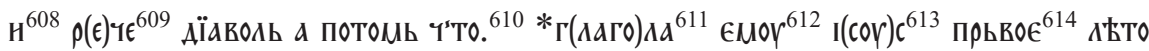

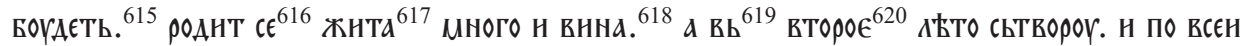
zеМАН ${ }^{621}$ не

$595 * \mathrm{C}$ : ндєже.

${ }^{596} \mathrm{H} \leftrightarrow$.

597 *П: ндєЖе ТЫ ХОџєШН ПрББНватН дїавОА Б, С $\leftrightarrow$.

${ }^{598} \mathrm{H}+\mathrm{H}$

${ }^{599} \mathrm{H}$ : свєжю.

${ }^{600} \mathrm{H}-1, * * \Pi:$ т8 хоџ४ те свєZатн.

${ }^{601} \Pi-1$.

602 3: везамн.

${ }^{603}$ Н, П: нєрБшнцнцн.

${ }^{604} \mathrm{H}, \Pi \leftrightarrow, 3-1$

${ }^{605} \mathrm{H}$, П: зємин.

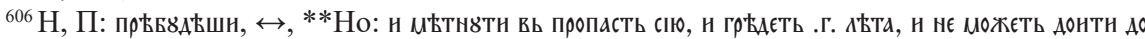

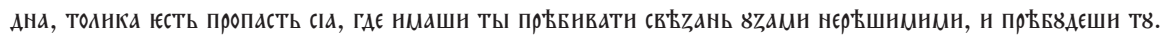

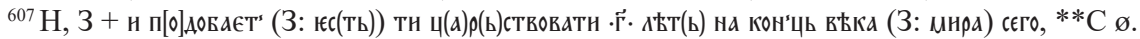

${ }^{608} \mathrm{H}+$ пакы.

${ }^{609} \mathrm{Ho}+$ เем8.

${ }^{610} \mathrm{H}+$ сьтворншн, Но, П + Б४деть (Но + Господн), С + Г(оспод)н. н.

${ }^{611}$ П, С: ptте.

${ }^{612} \mathrm{H}, \Pi, \mathrm{C}-1$.

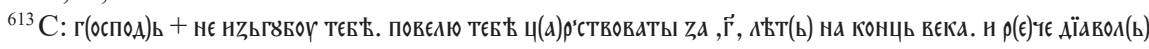
а $\omega$ ТОМ[ь] чТО Г(ОспОА $)$ н. н $\rho(\epsilon)$ чє Г(ОСПОА $)$ ь.

${ }^{614} \mathrm{H}:$ прьво, П: .А..

${ }^{615} \mathrm{H}, \Pi-1$.

${ }^{616} \mathrm{C}-2$.

${ }^{617}$ П: жнто.

${ }^{618}$ П, С: внно, С: 4, 2, 3, 1, С + вь людєх[ь].

${ }^{619} \Pi-2, \mathrm{C}-1$.

${ }^{620}$ П: .в..

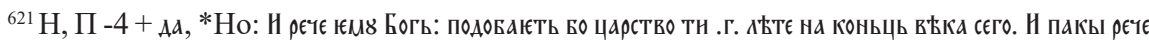

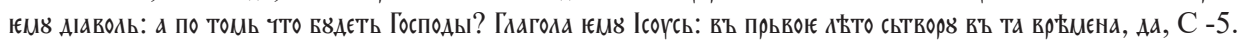

$6223-1$

${ }^{623}$ П, 3: сп४Аь.

${ }^{624} \mathrm{H}$, Но, П: жнта, С: теннцца.а

${ }^{625} \mathrm{C}$ : ведро.

${ }^{626}$ С: внно, Н, Но, П, С + по всєн zєМлн, Но + тєвБ радн, далволє. 


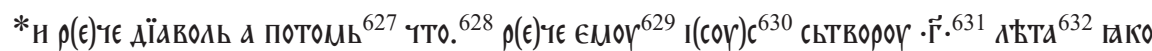

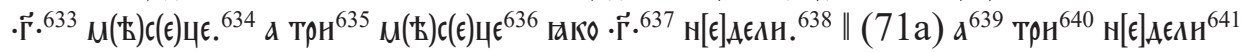

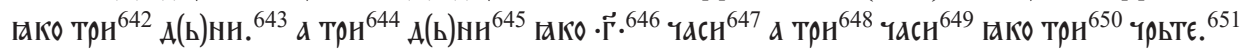

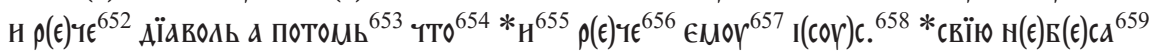

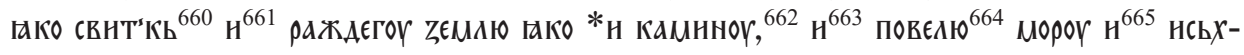

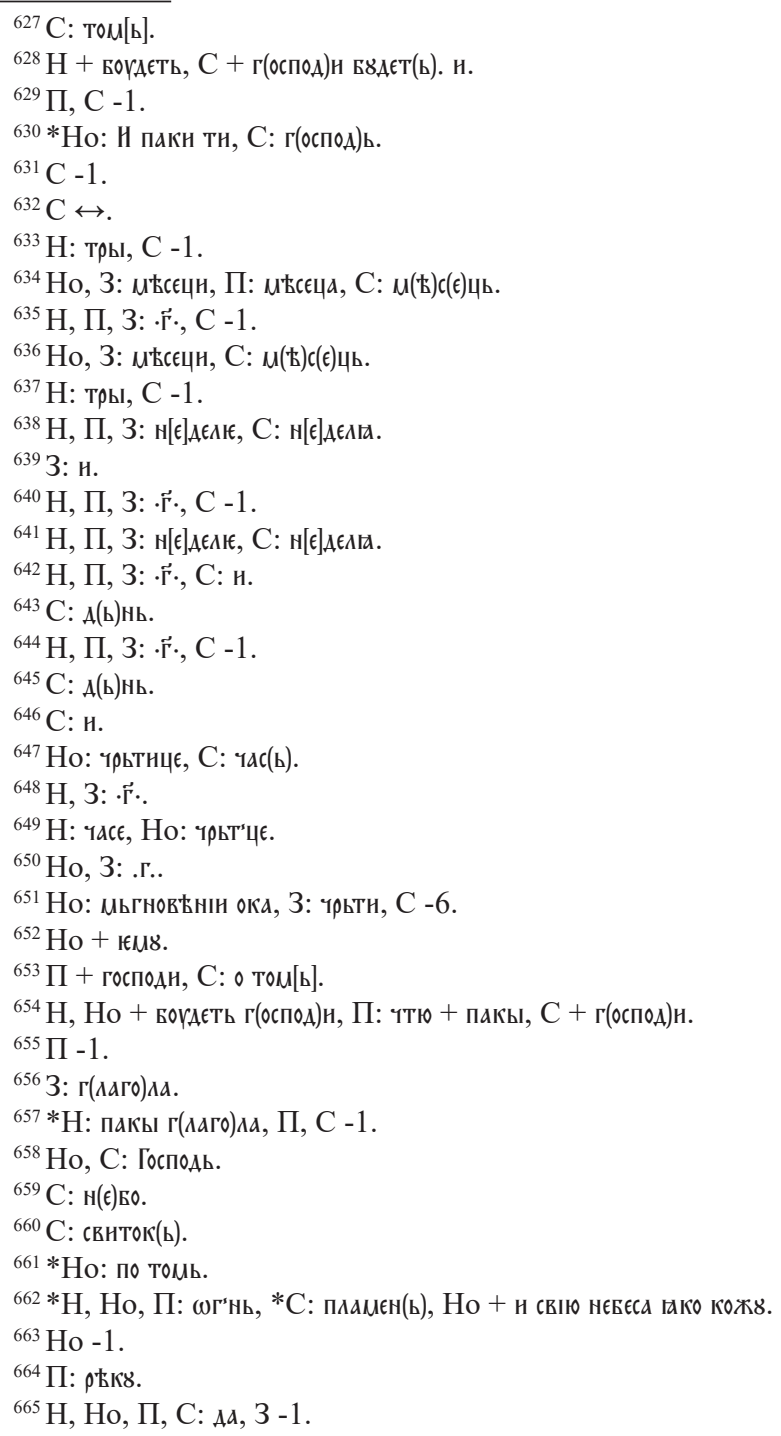




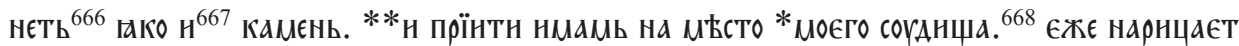

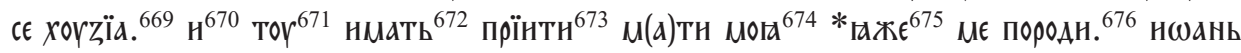

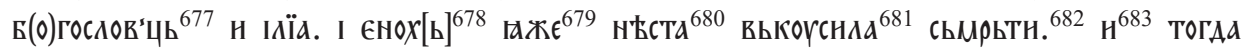

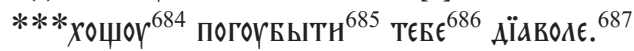

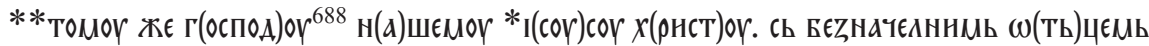

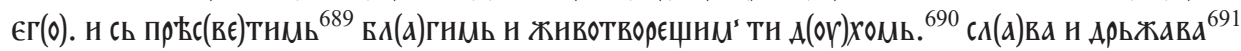

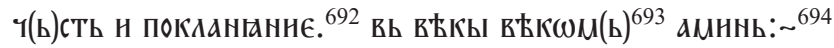

${ }^{666}$ Но: сьхнеть.

${ }^{667} \mathrm{H}, \mathrm{Ho}, \Pi-1$.

$668 *$ Н, П: своє, С -2.

${ }^{669} \mathrm{H}$ : хогzыє, П: хнжнна, **Но ø, С: хнднтт.

${ }^{670} \mathrm{H}, \Pi-1$.

${ }^{671}$ Но: тогад, C -1 .

${ }^{672} \mathrm{C}$ : нмам[ь].

${ }^{673}$ Н: прїндеть, Но: сьннтн.

${ }^{674} \mathrm{H}: 3,1,2$.

${ }^{675} \mathrm{H}:$ нжє, С: єжє.

${ }^{676} \mathrm{H}$, П, С: родн, П + н, *Но: на zемию.

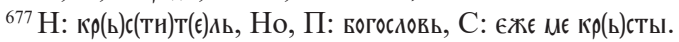

${ }^{678} \mathrm{H}+\mathrm{I \omega AH}$ 'Hь Б(0)госАОВ(ь)ць.

${ }^{679} \mathrm{H}$, Но, П, З: нжє.

${ }^{680} \mathrm{H}$, Но, П: нъсоүть, С: соүт(ь).

${ }^{681} \mathrm{H}$, Но, П: вьквснлн, С: вьквснле.

${ }^{682} \mathrm{C}$ : сьмьрть, Но, $\mathrm{C} \leftrightarrow, \mathrm{C}+$ нє.

${ }^{683} \mathrm{H}, \mathrm{C}-1$.

${ }^{684} \mathrm{H}$ : нмать, П: тє нмам, С -1.

${ }^{685} \mathrm{C}$ : погувв.

${ }^{686} \Pi-1, \mathrm{C}:$ Tє.

${ }^{687}$ П + Сь всємы агтелы твонмн, С: 2, 3, 1.

$688 * *$ Н, П: в (ог)в (Н: жє).

$6893+$ H.

$690 * \mathrm{H}, \Pi \varnothing$.

${ }^{691} \Pi-1$.

${ }^{692} \mathrm{H}-5$, П + оц४ н сын8 н свєтом४ А४х8 н нннга.

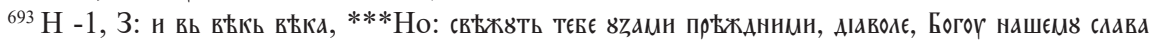
вь вЊКь.

${ }^{694} \Pi-4, * *$ С: Б(ог)8 нашєм४ слава вь вЊкы. 